\title{
Resilience of montado understorey to experimental precipitation variability fails under severe natural drought
}

\author{
Marjan Jongen $^{\mathrm{a}, *}$, Stephan Unger $^{\mathrm{b}}$, David Fangueiro ${ }^{\mathrm{a}}$, Sofia Cerasoli ${ }^{\mathrm{a}}$, João M.N. Silva ${ }^{\mathrm{a}}$, \\ João S. Pereira ${ }^{a}$ \\ a Instituto Superior de Agronomia, Universidade Técnica de Lisboa, Tapada da Ajuda, 1349-017 Lisboa, Portugal \\ ${ }^{\mathrm{b}}$ Department of Experimental and Systems Ecology, University of Bielefeld, Universitätsstr. 25, D-33615 Bielefeld, Germany
}

\section{A R T I C L E I N F O}

\section{Article history:}

Received 15 April 2013

Received in revised form 15 June 2013

Accepted 24 June 2013

Available online 23 July 2013

\section{Keywords:}

Precipitation manipulation

Drought

Understorey vegetation

Mediterranean ecosystem

Productivity

Soil inorganic nitrogen

\begin{abstract}
A B S T R A C T
Future climate scenarios for the Iberian Peninsula predict increasingly variable precipitation regimes, challenging key ecosystem processes in the Mediterranean biome. This study presents a large-scale water manipulation experiment, exposing the understorey vegetation in a Mediterranean oak woodland to simulations of precipitation variability. We hypothesized that, with no net changes in rainfall quantity, large infrequent precipitation events extend the period of soil moisture deficit, thereby decreasing productivity and soil nitrogen availability, accompanied by changes in plant community structure. However, the herbaceous understorey was highly resilient to increased precipitation variability. Extending the dry period between precipitation events from three to six weeks had no effect on productivity and community structure, this lack of responsiveness being attributed to phenotypic and physiological adaptations of the vegetation. However, vegetation senesced earlier, the shorter life cycle potentially influencing reproductive success. Additionally, experimental water manipulation did not affect soil nitrogen dynamics, with nitrogen being limiting in both treatments.

In comparison, non-manipulated control plots experienced a severe natural wintertime drought, significantly reducing productivity and affecting species composition, but showed less indication of nitrogen limitation. Thus, although the understorey vegetation was resilient to changes in precipitation variability, long drought periods exerted highly negative effects, with the vegetation not being able to buffer the drought effects through adaptive strategies when the length of the dry period exceeded $\sim 10$ weeks. Our results highlight the necessity for further studies investigating how climate change will influence the co-limitation of water and nitrogen availability, which in turn might affect plant productivity in Mediterranean ecosystems.
\end{abstract}

(C) 2013 Elsevier B.V. All rights reserved.

\section{Introduction}

Mediterranean climate in the Iberian Peninsula is characterized by hot and dry summers and relatively mild and wet winters. The native vegetation has evolved adaptive strategies to avoid or endure severe summer droughts, when high temperatures and low soil moisture set the abiotic limits for productivity (e.g. Tenhunen et al., 1990). The evergreen oak woodlands, called montados in Portugal, are unique savanna-type agro-silvo-pastoral ecosystems. They are characterized by a diverse understorey vegetation, resembling Mediterranean grasslands, and dominated by C3 annual plant species, avoiding the dry hot summer period by adjusting their lifecycle to the seasonal water availability (e.g. Unger et al., 2009). Previous studies showed that the montado understorey vegetation

\footnotetext{
* Corresponding author. Tel.: +351 21365 3515; fax: +351 213655000.

E-mail address: marjanjongen@isa.utl.pt (M. Jongen).
}

plays a significant role for ecosystem functioning (Jongen et al., 2011; Pereira et al., 2007). For example, the herbaceous understorey vegetation can account for more than $50 \%$ of ecosystem gross primary productivity in spring (Unger et al., 2009). In addition, understorey vegetation has been shown to enhance nitrogen input and retention within the ecosystem (Moreno Marcos et al., 2007; Otieno et al., 2011), and significantly reflect on ecosystem evapotranspiration (Paço et al., 2009) and soil water dynamics (Dubbert et al., 2013).

Climate change scenarios for the Mediterranean region predict increasing annual mean temperatures and decreasing annual precipitation (Christensen et al., 2007), the latter accompanied by changes in seasonality and temporal variability of precipitation (Luterbacher et al., 2006), with a decrease in the number of precipitation days and an increase in the length of the dry spells (Easterling et al., 2000). As a consequence, the risk of drought in Mediterranean ecosystems is likely to increase (Christensen et al., 2007; Giorgi and Lionello, 2008). Indeed, studies report an increase in 
the dry period between precipitation events in the Iberian Peninsula (Gallego et al., 2011), with increasing drought frequency in Portugal for the February to March period (Pires, 2003). In addition, recent studies (Hoerling et al., 2012; Kelley et al., 2012) indicate a decrease in the Mediterranean region's cold season precipitation, with drier conditions and increased wintertime drought frequency since $\sim 1970$. In Iberia the wintertime drought of 2004/2005 was the driest event on record, with the southern half of the Iberian Peninsula receiving merely $\sim 40 \%$ of the usual precipitation by June 2005 (Garcia-Herrera et al., 2007). For a Mediterranean grassland, this resulted in severe limitations of primary productivity ( $\sim 4$ fold), and a large reduction of carbon sequestration (Aires et al., 2008; Jongen et al., 2011; Pereira et al., 2007).

Grassland dominated ecosystems are commonly considered very sensitive to climatic changes (e.g. Grime et al., 2000), especially to changes in precipitation (Nippert et al., 2006; Yang et al., 2008), with the interannual variation in aboveground net primary productivity (ANPP) being correlated with the interannual variation in precipitation (Jongen et al., 2011; Sala et al., 1988; Vázquez-de-Aldana et al., 2008). In addition, studies have shown that ANPP is sensitive not only to the size but also to the timing and size of precipitation inputs (Cherwin and Knapp, 2012; Fay et al., 2008; Heisler-White et al., 2009; Swemmer et al., 2007), suggesting that increases in precipitation variability will affect ANPP. However, several studies with experimentally manipulated precipitation variability, without altering total precipitation inputs, demonstrated that the relationship between precipitation variability and interannual variation in ANPP remains open to debate, with an ecosystem's sensitivity to precipitation variability depending on vegetation structure, species composition, soil characteristics and climate zone. For example, in mesic grasslands, increasing precipitation variability decreased ANPP (Fay et al., 2003, 2008; Harper et al., 2005; Heisler-White et al., 2009; Knapp et al., 2002), while in an arid ecosystem (Thomey et al., 2011) and in a semi-arid shortgrass steppe (Heisler-White et al., 2009), increasing precipitation variability increased ANPP. However, in a Mediterranean grassland, dominated by annual species, changes in precipitation variability had no effect on ANPP (Miranda et al., 2009). Similarly, a previous study on the effects of precipitation variability on ecosystem processes in the herbaceous understorey in a Mediterranean oak woodland, with the dry period extended from one to three weeks, showed no significant effects on ANPP and community structure (Jongen et al., 2013b).

Although the strong dependence of ecosystem functioning on water availability in Mediterranean and other semi-arid regions has been long recognized (Bugalho et al., 2011; Pereira et al., 2007; Rodriguez-Iturbe and Porporato, 2004; Vicente-Serrano et al., 2010), these ecosystems are also frequently reported as nitrogenlimited (Rutigliano et al., 2009), with primary productivity being co-limited by soil moisture and plant available nitrogen (Cossani et al., 2010; Epstein et al., 2005). As the nitrogen cycle in semiarid systems is strongly linked with drying/wetting cycles (Austin et al., 2004; Borken and Matzner, 2009; Saetre and Stark, 2005), changes in precipitation variability have been shown to influence nutrient release processes, plant available nitrogen and nitrogen losses (Dijkstra et al., 2012; Heisler-White et al., 2009; Yahdjian and Sala, 2010).

To develop a better understanding of the effects of altered precipitation regimes on ecosystem $\mathrm{C}$ and $\mathrm{N}$ cycling processes, we established a large-scale rainfall manipulation experiment in a typical Mediterranean oak woodland. The aim was to predict the impact of increasing precipitation variability, without altering total annual precipitation inputs, on productivity and species composition of the understorey vegetation, as well as its interrelations with belowground parameters, such as soil inorganic nitrogen, water infiltration and nitrogen leaching. In addition, control plots allowed for comparison of these parameters under a natural precipitation regime. We hypothesized that, with no net changes in rainfall quantity, large infrequent precipitation events will extend the period of soil moisture deficit, thereby decreasing ANPP and changing plant community structure, as compared to small, frequent precipitation events. In addition, we hypothesized that large, infrequent precipitation events will increase water infiltration to deeper soil layers, with a concomitant increase in $\mathrm{N}$ leaching, leading to a decrease of soil $\mathrm{N}$ availability and thus exacerbating the negative impact of drought on the understorey vegetation. Our results contribute to an improved understanding of the effects of climate change mediated alterations in water availability on productivity and its feedbacks on the soil $\mathrm{N}$ cycle in Mediterranean ecosystems.

\section{Materials and methods}

\subsection{Site description}

The study was conducted at the Herdade da Machoqueira do Grou ( $\left.39^{\circ} 08^{\prime} 16^{\prime \prime} \mathrm{N}, 8^{\circ} 20^{\prime} 03^{\prime \prime} \mathrm{W}\right), 30 \mathrm{~km}$ northeast of Coruche, Portugal. The soil is a Cambisol (FAO, 2006), with $81 \%$ sand, $14 \%$ silt and $5 \%$ clay. Field capacity at a depth of $5 \mathrm{~cm}$, measured as the volumetric water content of the soil two days after a large irrigation event $(80 \mathrm{~mm})$, is $19.3 \%$ ( $\mathrm{SE}=0.44, n=16)$. Volumetric soil water content at the permanent wilting point, measured at $-1.5 \mathrm{MPa}$ using a pressure plate extractor, is $7.6 \%(\mathrm{SE}=0.24, n=12)$. The climate is Mediterranean, characterized by wet and mild winters, and dry and hot summers. Long-term mean annual temperature is approximately $15.9^{\circ} \mathrm{C}$, and long-term mean annual precipitation is $680 \mathrm{~mm}$ (Inst. de Meteorologia, Lisbon). The study site is an evergreen oak woodland (montado) with Quercus suber being the only tree species. The understorey vegetation consists of a mixture of C3 annual species, emerging after the first rains in autumn and senescing in late spring. Species composition and productivity of the understorey vegetation resembles that found in Mediterranean grasslands. The dominant species are Rumex acetosella, Tuberaria guttata, Tolpis barbata, Plantago coronopus, Agrostis pourretii, Vulpia bromoides and $V$. geniculata.

Until October 2009, the experimental site was intermittently grazed with a stocking density of 0.16 cattle ha ${ }^{-1}$. In October 2009 , the site was ploughed and seeded with a mixture of legumes (Trifolium subterraneum, T. michelianum - balansae, T. resupinatum, $T$. vesiculosum, T. incarnatum, T. glanduliferum, Biserrula pelecinum, Ornithopus sativus, O. compressus) and the grass Lolium multiflorum, this seed mixture (Charneca 650, S 07874) being supplied by Fertiprado, Vaiamonte, Portugal. Sowing legume-rich seed mixtures in agro-silvo-pastoral systems, in order to improve productivity and soil fertility, is a common agricultural practice in Portugal (Crespo, 2010). Aboveground productivity of the understorey vegetation in May 2010 and May 2011 was 283 and $196 \mathrm{~g} \mathrm{~m}^{-2}$, respectively.

\subsection{Experimental design and rainfall manipulation}

In December 2009, eight rainfall manipulation shelters ('Fraga', Prilux, Ponte de Vagos, Portugal) were constructed within a fenced area of $\sim 3500 \mathrm{~m}^{2}$ with a tree density of $\sim 45$ trees ha $^{-1}$, enabling manipulation of the precipitation received by the understorey. Each shelter covered an area of $6 \mathrm{~m} \times 5 \mathrm{~m}\left(30 \mathrm{~m}^{2}\right)$, with an eave height of $1.6 \mathrm{~m}$ and a ridge height of $2.5 \mathrm{~m}$. The shelter roofs were covered on November 17, 2011 by a clear, $0.2 \mathrm{~mm}$, UV-transparent polyethylene greenhouse film (Plásticos F. Matos, Massamá, Portugal). For additional information on shelter design see Jongen et al. (2013b). Water was applied to the experimental plots using an irrigation system, consisting of four 18-VAN rotary sprinklers with $90^{\circ}$ arc nozzles (Rainbird, Azusa, USA), one in each corner of the 
experimental plots. The water manipulation treatment was based on historical precipitation data (1955-2007) for the experimental site (Inst. de Meteorologia, Lisbon). Average annual precipitation is $680 \pm 210 \mathrm{~mm}$, with $87 \%$ (594 $\mathrm{mm}$ ) of the precipitation being confined to the growing season (October 1 to May 31). Historical precipitation data give a median number of rain events during the growing season of 24 , with the median length of the dry periods being 7 days. The two water manipulation treatments were: '3weekly watering treatment', with the normal dry period increased three-fold to 21 days, and ' 6 -weekly watering treatment', with the normal dry period increased six-fold to 42 days. In addition to the two water manipulation treatments, there were non-sheltered 'control' plots, receiving natural precipitation. Each of the three treatments had four replicate experimental plots. To prevent a treatment effect on germination and seedling establishment, all experimental plots were subjected to equal water inputs until the middle of November 2011, receiving $244 \mathrm{~mm}$ of natural precipitation. From November 17 onwards, when the shelters were covered, the 3-weekly watering treatment received $40 \mathrm{~mm}$ of water every three weeks and the 6 -weekly watering treatment received $80 \mathrm{~mm}$ every six weeks. In total, precipitation inputs during the growing season of October 2011 to the end of May 2012 amounted to $614 \mathrm{~mm}$ for both treatments.

\subsection{Microclimate}

Air temperature and humidity were continuously measured using EHT sensors with radiation shields (Decagon Devices, Pullman, USA). Water vapour pressure deficit (VPD) was calculated from the temperature and humidity data according to Goudriaan and van Laar (1994), and presented as the average values for the 11:00-18:00 h period. Photosynthetic photon flux density (PPFD) was continuously measured using a QSO-S PAR sensor (Decagon Devices, Pullman, USA). One EC-5 soil moisture sensor (Decagon Devices, Pullman, USA) was installed in the middle of each of the experimental plots at a depth of $5 \mathrm{~cm}$, continuously measuring volumetric soil water content (SWC). All above-mentioned sensors were connected to EM-50 data loggers (Decagon Devices, Pullman, USA), recording half-hourly means. Data on volumetric SWC at a depth of $10,20,30,40,60$ and $100 \mathrm{~cm}$ was obtained using soil profile probes (PR1, Delta-T Devices, Cambridge, UK), with measurements made $1 \mathrm{~h}$ before and $24 \mathrm{~h}$ after each watering event. PR1 data were used to estimate infiltration, calculated as the increase in the amount of water $\left(\mathrm{l} \mathrm{m}^{-2}\right)$ in different soil layers $24 \mathrm{~h}$ after watering as compared to pre-watering values. Infiltration was calculated in the water manipulation plots, in conjunction with the irrigation events on January 3, February 14, March 27 and May 7. Precipitation was measured with a RG2 rain gauge (Delta-T Devices, Burwell, Cambridge, UK), and stored as half-hourly means on a DL2 data logger (Delta-T Devices, Burwell, Cambridge, UK).

\subsection{Primary productivity and vegetation indices}

Germination of the herbaceous understorey in the studied montado ecosystem occurs in autumn after the first substantial precipitation event, with biomass development primarily confined to the period between February and May. Therefore, aboveground net primary productivity (ANPP) was estimated on February 16, March 27, May 10 and June 12, the latter two dates corresponding with the onset of senescence. All plant material in two $30 \mathrm{~cm} \times 30 \mathrm{~cm}$ quadrats within each experimental plot was harvested, sorted into the individual species, oven dried at $60^{\circ} \mathrm{C}$ for $72 \mathrm{~h}$, and weighed. Estimations of vegetation height were conducted around the sampling dates for ANPP. Within each experimental plot, 10 replicate measurements of plant height were recorded, measuring from the soil level to the top of the vegetation, including flowering stems.
Belowground net primary productivity (BNPP) was estimated at the end of the growing season (June 12). In each of the experimental plots, three soil cores of $8 \mathrm{~cm}$ diameter and a depth of up to $20 \mathrm{~cm}$ were taken. Roots were washed out, with subsequent analysis of root length for determination of specific root length (SRL) using WinRhizo software (Regents Instruments Inc., Canada), then oven dried at $60^{\circ} \mathrm{C}$ for $72 \mathrm{~h}$, and weighed.

On May 30, leaf area index (LAI) was measured using a ceptometer (AccuPAR model LP-80, Decagon Devices, Pullman, USA), allowing an indirect determination of LAI by measuring the fraction of intercepted photosynthetically active radiation (fPAR) of the canopy.

Using a FieldSpec3 spectroradiometer (ASD Inc., Boulder, USA), canopy reflectance measurements in the range of $350-2500 \mathrm{~nm}$ were performed on May 25 and June 11, to assess vegetation senescence. The spectral resolution (Full-Width-Half-Maximum) is $3 \mathrm{~nm}$ at $700 \mathrm{~nm}$ and $10 \mathrm{~nm}$ at $1400 \mathrm{~nm}$ and $2100 \mathrm{~nm}$. The sampling interval is $1.4 \mathrm{~nm}$ for the spectral region of $350-1000 \mathrm{~nm}$ (visible and near infrared) and $2 \mathrm{~nm}$ for the spectral region of $1000-2500 \mathrm{~nm}$ (short-wave infrared). On both dates, the measurements were conducted around solar noon, with three replicates in each experimental plot, each replicate representing the average of 5 spectra with the bare fiberoptic cable ( $25^{\circ}$ degree of field-of-view) inserted into a pistol grip at a height of $70 \mathrm{~cm}$ from the soil. A white reference of known reflectance (Spectralon panel, Labsphere, Inc., North Sutton, USA) was used to normalize for variations in atmospheric conditions and to convert the measurements into absolute reflectance. Three vegetation indices were calculated using reflectance in selected wave bands: (1) Normalised Difference Vegetation Index $(\mathrm{NDVI})=\left(\rho_{841-876}-\rho_{620-670}\right) /\left(\rho_{841-876}+\rho_{620-670}\right)$, (2) Red Edge Normalised Difference Vegetation Index $\left(\mathrm{NDVI}_{705}\right)=\left(\rho_{750}-\rho_{705}\right) /\left(\rho_{750}+\rho_{705}\right)$, and (3) Cellulose Absorption Index $(\mathrm{CAI})=0.5\left(\left(\rho_{2000}-\rho_{2200}\right) / \rho_{2100}\right)$. NDVI and $\mathrm{NDVI}_{705}$ are indicators of canopy structure, green biomass, LAI and chlorophyll content (Gamon et al., 1995), these indices decreasing with increasing canopy senescence (Di Bella et al., 2004; Viña and Gitelson, 2005). CAI, although usually used as indicator of crop residue (Aguilar et al., 2012; Nagler et al., 2003; Serbin et al., 2009), has been shown to be a diagnostic tool to estimate senescence in vegetation (Chabrillat, 2006). CAI represents the presence of cellulose, with plant senescent material typically featuring positive CAI values (Nagler et al., 2003).

\subsection{N dynamics}

To determine plant nitrogen content, $0.3 \mathrm{~g}$ of ground plant material was digested with $2.5 \mathrm{ml}$ of concentrated sulphuric acid with selenium as catalyst, with subsequent $\mathrm{N}$ analysis by automated segmented-flow spectrophotometry (SanPlus, Skalar Analytical B.V., Breda, the Netherlands) using the Berthelot method (Houba et al., 1989).

Soil sampling, for determination of soil $\mathrm{NO}_{3}{ }^{-}-\mathrm{N}$ and $\mathrm{NH}_{4}{ }^{+}-\mathrm{N}$, was done at 6-weekly intervals, before and after each 6-weekly watering event. From each of the experimental plots, four duplicate soil cores ( $2 \mathrm{~cm}$ diameter, $0-10 \mathrm{~cm}$ ) were pooled, mixed to achieve uniformity, and subsequently sieved. $\mathrm{NO}_{3}{ }^{-}-\mathrm{N}$ and $\mathrm{NH}_{4}{ }^{+}-\mathrm{N}$ were extracted by shaking $8 \mathrm{~g}$ of soil with $20 \mathrm{ml} 2 \mathrm{M} \mathrm{KCl}$ for $1 \mathrm{~h}$. Extracts were analyzed by automated segmented-flow spectrophotometry (SanPlus, Skalar Analytical B.V., Breda, the Netherlands) using the Berthelot and hydrazinium reduction method, and the sulfanilamide diazotizing method for $\mathrm{NH}_{4}{ }^{+}-\mathrm{N}$ and $\mathrm{NO}_{3}{ }^{-}-\mathrm{N}$, respectively (Houba et al., 1989).

Plant available $\mathrm{NO}_{3}{ }^{-}-\mathrm{N}$ and $\mathrm{NH}_{4}{ }^{+}-\mathrm{N}$ was measured with PST1 ion-exchange resin capsules (Unibest Inc., Bozeman, USA) filled with mixed anion-cation resins. Capsules were installed in December 2011, into the main rooting zone at $10 \mathrm{~cm}$ depth, with 


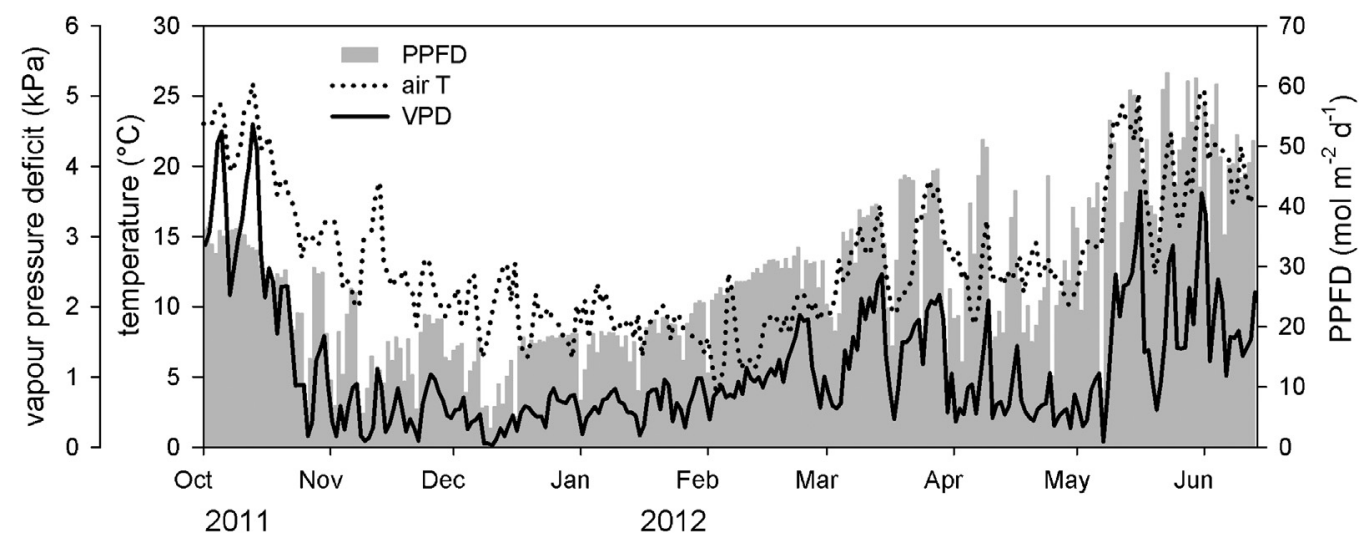

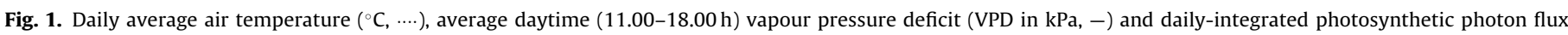
density (PPFD in $\mathrm{mol} \mathrm{m}^{-2} \mathrm{~d}^{-1}, \square$ ) at the experimental site over the course of the study.

five replicates per experimental plot. Capsules were collected in June 2011, with subsequent stripping of adsorbed ions by sequential shaking in two batches of $20 \mathrm{ml} 2 \mathrm{M} \mathrm{KCl}$. Extracts were analyzed for $\mathrm{NH}_{4}{ }^{+}-\mathrm{N}$ and $\mathrm{NO}_{3}{ }^{-}-\mathrm{N}$ as described above.

Using pore water samplers (SK20 suction cups, UMS GmbH, München, Germany) in connection with a vacuum system (VSpro, UMS GmbH, München, Germany), soil pore water at a depth of $30 \mathrm{~cm}$ was collected between February and May, by applying a constant vacuum (between 25 and $30 \mathrm{kPa}$, depending on SWC and plot elevation) during 24-h periods, starting at the time of the respective 6-weekly watering events. A total of twelve pore water samplers were installed; three pore water samplers in half of the water manipulation plots. Subsequently, $\mathrm{NO}_{3}{ }^{-}-\mathrm{N}$ and $\mathrm{NH}_{4}{ }^{+}-\mathrm{N}$ was analyzed in the collected water as described above.

\subsection{Data analysis}

Statistical analysis was performed using Sigmaplot 11.0 (Systac Software, Inc., San Jose, USA). Significance level was set to $p<0.05$. Data on LAI, BNPP, root to shoot ratio, SRL and nitrogen availability were analyzed using a one-way analysis of variance (ANOVA), with treatment being the only factor. Data on ANPP, vegetation height, spectral indices, tissue and herbage $\mathrm{N}$ were analyzed using a two-way repeated measures ANOVA, with treatment and date as factors. When a significant difference was found for a main factor, Fisher's LSD post hoc pairwise comparison was applied to determine individual differences between means. Data on infiltration were analyzed using a two-way ANOVA, with treatment and soil depth as factors. Data on the relative abundance of functional groups were arcsine transformed to ensure normality, and analyzed using a two-way repeated measures ANOVA, with treatment and date as factors. Data on seasonal pattern of soil inorganic $\mathrm{N}$ failed to meet the normality assumptions for ANOVA despite transformations, and were analyzed using non-parametric Kruskal-Wallis ANOVA on ranks for all-over treatment effects, and Friedman repeated measures ANOVA on ranks for all-over date effects. Data on soil inorganic N of the two experimental watering treatments around individual watering events were analyzed using a two-way repeated measures ANOVA, with treatment and date as main effects.

\section{Results}

\subsection{Microclimate and soil water}

Daily average air temperature at the experimental site over the course of the study ranged from 3.9 to $25.9{ }^{\circ} \mathrm{C}$ (Fig. 1 ), with daily-integrated PPFD varying between 3.1 and $62.1 \mathrm{~mol} \mathrm{~m}^{-2} \mathrm{~d}^{-1}$.
October was warm, with a monthly average temperature of $19.9^{\circ} \mathrm{C}$, as compared to the long-term (1981-2010) average of $17.5^{\circ} \mathrm{C}$ (Inst. de Meteorologia, Lisbon). In February and April temperatures were below average. March, on the other hand, was relatively warm, and characterized by two warm spells in the period of March 9-14 and March 25-28, with above-average daily maximum temperatures ranging from 24.4 to $27.9^{\circ} \mathrm{C}$, and VPD between 1.8 and $2.5 \mathrm{kPa}$.

As usual in this Mediterranean climate, May saw a rapid increase in temperature, with daily maximum temperature in the period of May 8 to June 13 exceeding $30^{\circ} \mathrm{C}$ on 15 occasions, with concomitant high VPD (1.6-3.6 kPa).

Total precipitation in the growing season (October 2011 until June 2012) was $412.6 \mathrm{~mm}$, 30\% below the long-term growing season average. Most of the precipitation $(294 \mathrm{~mm})$ was confined to the period of October 23 to December 16 (Fig. 2a). Subsequently followed an exceptionally severe wintertime drought with a total precipitation of merely $10.2 \mathrm{~mm}$ between December 17 and March 31 , with the long-term average for this period being $\sim 280 \mathrm{~mm}$. Precipitation in April and May (62.6 and $45.5 \mathrm{~mm}$ respectively) was normal, with the long-term average for these months adding up to $109.2 \mathrm{~mm}$. The control plots only received natural precipitation, and as a result of the drought, SWC in these plots reached the wilting point $\sim 10$ weeks after the last substantial natural precipitation, and was below the wilting point during the period of February 26 to April 1 (Fig. 2b), exerting a strong effect on plant performance. In addition, SWC in the control plots was below the wilting point in the period of April 8-25, on May 18 and from May 23 onwards. Our experimental water manipulation (Fig. 2c) resulted in marked differences in temporal soil moisture dynamics between the 3and 6-weekly watering treatments (Fig. 2d). At the start of water manipulation (November 17) SWC in these plots was 17.6\%. Except for two of the days after irrigation (December 13 and January 24), in the period until March 6, SWC in the 3-weekly watering treatment was lower as compared to the 6-weekly watering treatment. Subsequently, supremacy of SWC alternated between these two treatments and higher temperatures in combination with increasing biomass and concomitant higher transpiration, resulted in a rapid decrease in SWC in both treatments. This resulted in the SWC in the 6-weekly watering treatment being below the wilting point on March 16-26, April 24-May 8 and from May 27 onwards. In the 3-weekly watering treatment SWC was below the wilting point for two brief periods in March and April (March 25-27 and April 15-17) and for the period of May 20-29. Total number of days during spring with SWC below the wilting point was 13, 42 and 74 days in the 3-weekly, 6-weekly and control treatments, respectively. Average SWC at $5 \mathrm{~cm}$ depth during the growing season was $13.0 \%$, $13.4 \%$ and $11.6 \%$ in the 3-weekly, 6 -weekly and control treatments, respectively. The variability of SWC, calculated as the coefficient 

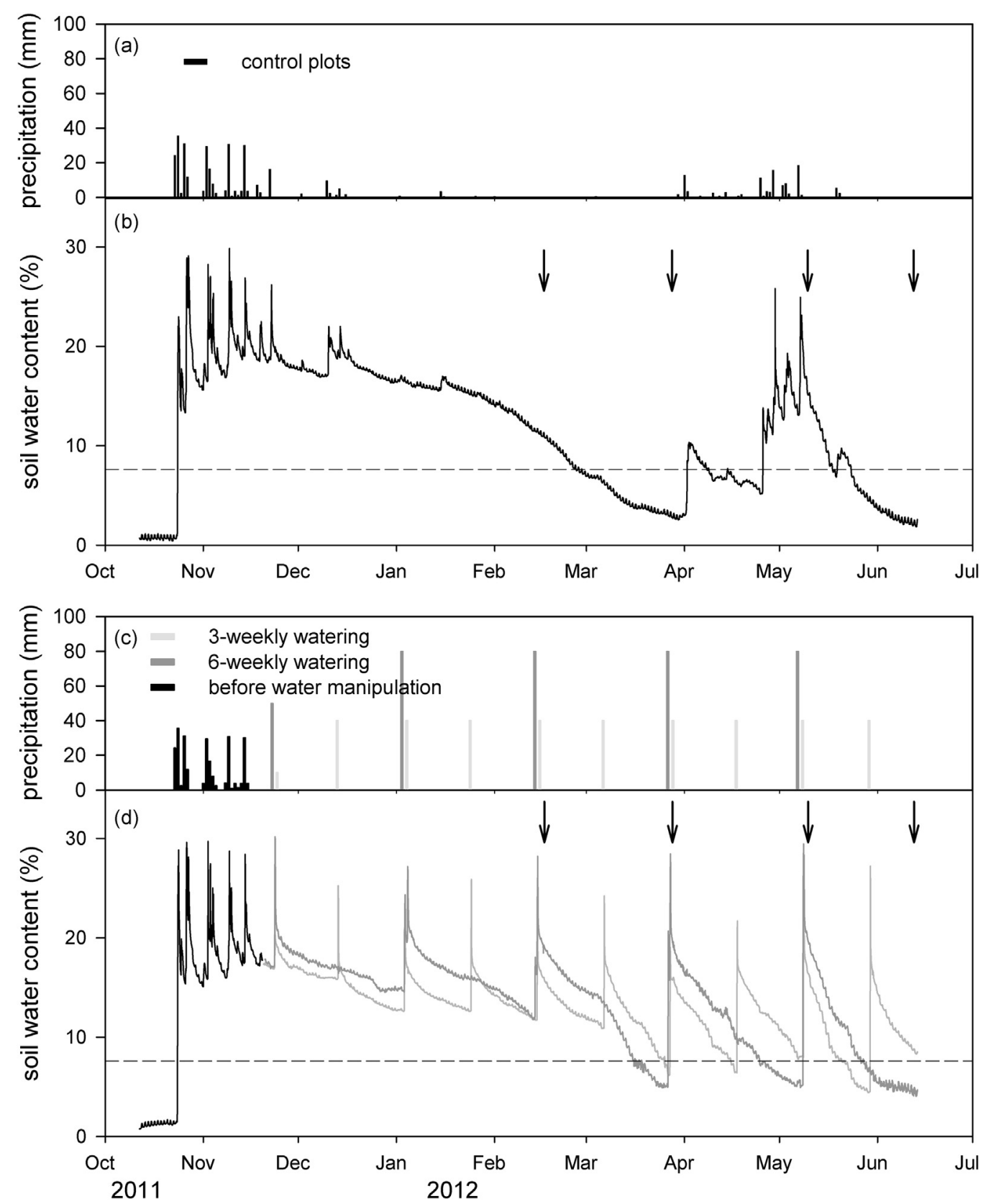

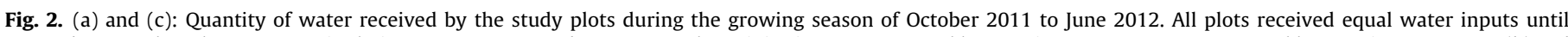

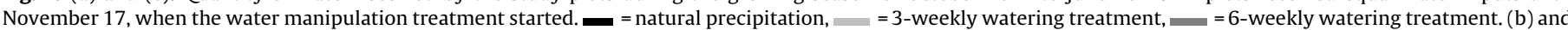

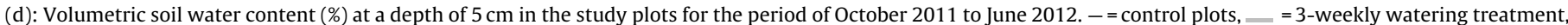

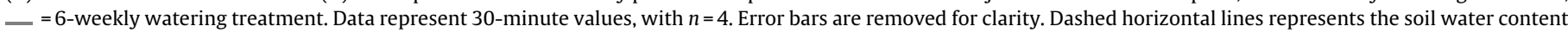
at the permanent wilting point, indicating the threshold for soil water stress. Vertical arrows indicate timing of harvesting for ANPP.

of variation of daily average SWC values, increased by $23 \%$ (from 0.326 to 0.401 ) when extending the dry period from three to six weeks. However, in the control plots, variability of SWC was 0.541 , markedly higher as compared to the two water manipulation treatments.

Water infiltration through the soil profile, which is an indication of water retention capacity of the soil with large precipitation events, was assessed $24 \mathrm{~h}$ after irrigation in the water manipulation plots (Fig. 3). Experimental precipitation patterns resulted in significant differences in water infiltration in deeper $(>50 \mathrm{~cm})$ soil layers. In the 3-weekly watering treatment, soil moisture in the $70-100 \mathrm{~cm}$ deep soil layer increased by $1.1 \mathrm{l} \mathrm{m}^{-2}$, as compared to a $4.61 \mathrm{~m}^{-2}$ increase in the 6 -weekly watering treatment (Fig. 3). This difference was less pronounced in the $50-70 \mathrm{~cm}$ deep soil layer.
Cumulative infiltration in the $0-100 \mathrm{~cm}$ soil profile in the 3 -weekly watering treatment amounted to $401 \mathrm{~m}^{-2}$, thus accounting for all the water applied. In contrast, in the 6-weekly watering treatment, these plots receiving $801 \mathrm{~m}^{-2}$, cumulative infiltration only amounted to $571 \mathrm{~m}^{-2}$, with possible explanations of this disparity being surface run-off, subsurface lateral flow, or infiltration to soil layers $>100 \mathrm{~cm}$.

\subsection{Primary productivity and vegetation indices}

Seasonal dynamics of sward development of the herbaceous vegetation is primarily confined to the period between February and May. All-over ANOVA showed a significant treatment effect $(p=0.002)$, date effect $(p<0.001)$ and interaction $(p=0.006)$ on both 


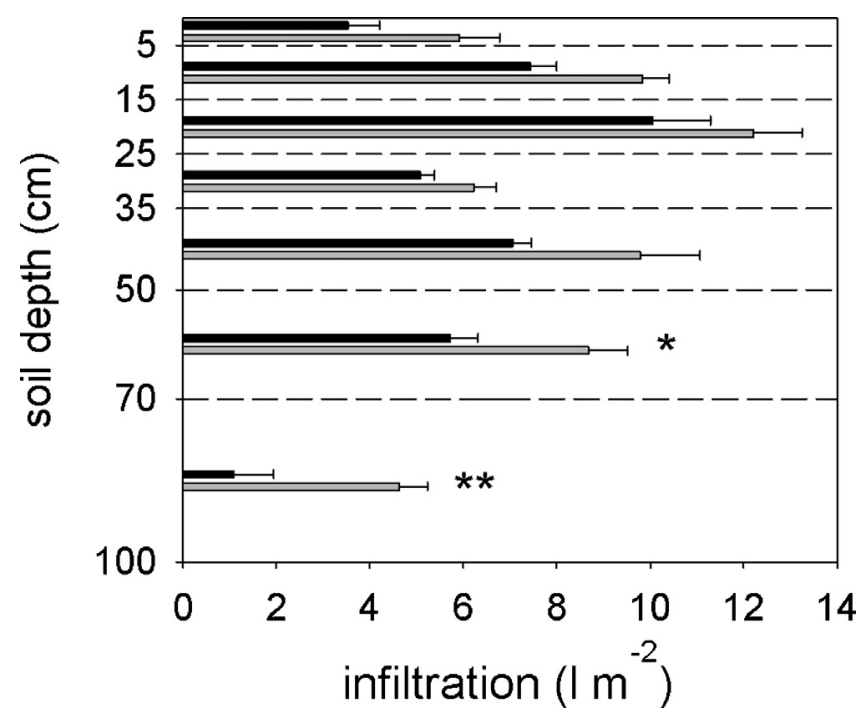

Fig. 3. Water infiltration through the soil profile. Data represent the increase in the amount of water in the respective soil layer $24 \mathrm{~h}$ after the watering events, with $\mathbf{\square}=3$-weekly watering treatment and $\square=6$-weekly watering treatment. Bars represent mean $\pm \mathrm{SE}, n=16$. Asterisks mark significant differences $\left({ }^{*} p<0.05,{ }^{* *} p<0.01\right)$ between treatments.

ANPP and vegetation height, with the control plots being significantly different from the two experimental watering treatments (Fig. 4). Post hoc analysis show significantly lower ANPP and vegetation height in the control plots in March, May and June. In February, no significant difference was found in vegetation height between the treatments, while ANPP in the control plots was significantly lower as compared to the 6-weekly watering treatment, with ANPP values in February of $83 \pm 11.0,118 \pm 13.5$ and $55 \pm 12.4 \mathrm{~g} \mathrm{~m}^{-2}$ in the 3-weekly, 6-weekly and control treatment, respectively.

Over the growing season, ANPP in the 3- and 6-weekly watering treatment significantly increased, reaching a peak in late spring, with ANPP in May being $241 \pm 33.5 \mathrm{~g} \mathrm{~m}^{-2}$ in the 3-weekly watering treatment, and $236 \pm 39.7 \mathrm{~g} \mathrm{~m}^{-2}$ in the 6 -weekly watering treatment. In the control plots, however, ANPP did not show a significant increase over the growing season, with values in May of only $80 \pm 7.7 \mathrm{~g} \mathrm{~m}^{-2}$. Vegetation height for all treatments showed a significant increase along the growing season, with the exception of vegetation height in the control plots between February and March. At the end of May, vegetation height was $21 \pm 0.9,22 \pm 1.0$ and $16 \pm 1.2 \mathrm{~cm}$ in the 3 -weekly, 6 -weekly and control treatment, respectively.

LAI, measured at the end of May, was significantly different between treatments, with the LAI in the control plots being lower as compared to that in the 3-and 6-weekly watering treatment (Table 1). Although the presence of inflorescences and maturing fruits may have resulted in an overestimation of LAI, ANPP showed a good correlation with LAI $\left(r^{2}=0.84, p<0.001\right.$, slope $\left.=0.06\right)$.

BNPP was not significantly $(p=0.176)$ affected by treatment. However, dry matter partitioning, calculated as the root to shoot ratio, was significantly $(p=0.004)$ higher in the control plots, this
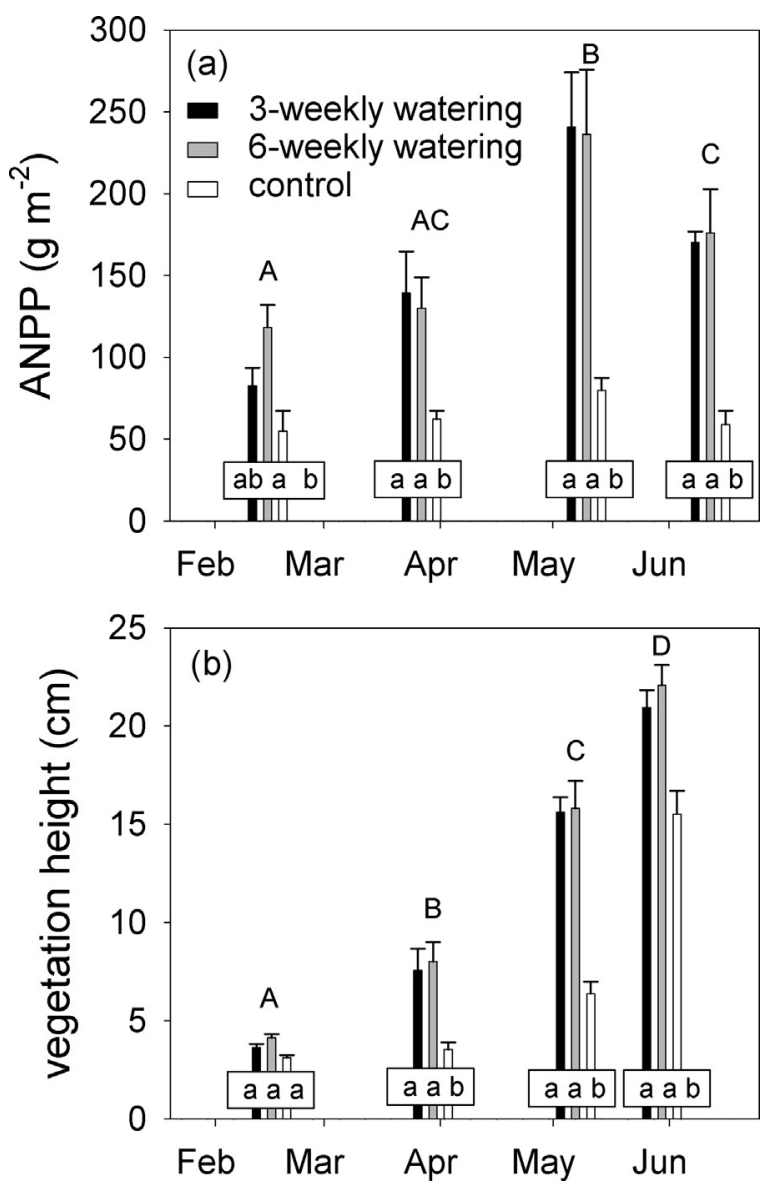

Fig. 4. (a) Aboveground net primary productivity (ANPP) and (b) vegetation height in the 3-weekly ( $\square$ ) and 6-weekly ( $\square$ ) watering treatments, and control plots ( $\square$ ) along the growing season. Bars represent mean $\pm \mathrm{SE}, n=4$. Different letters indicate significantly different means (Fisher's LSD, $p<0.05$ ) between date (capital letters) and treatment at each harvest (lower-case letters).

difference resulting from the low ANPP in these plots. SRL, an indicator of resource uptake potential, was significantly $(p=0.039)$ affected by treatment, with a lower SRL in the control plots as compared to the 6-weekly watering treatment.

The vegetation indices NDVI, NDVI 705 and CAI were significantly affected by date $(p<0.001)$, with a decrease in NDVI and $\mathrm{NDVI}_{705}$ and an increase in CAI on June 11 as compared to May 25 (Fig. 5), all indicating a higher degree of canopy senescence in June. The three indices were significantly affected by treatment $(p<0.001)$. In addition, the interaction between treatment and date was significant (NDVI: $p=0.043$ NDVI $_{705}: p=0.025$ and CAI: $p=0.038$ ). On May 25 NDVI and NDVI $_{705}$ in the control plots were lower as compared to the two experimental watering treatments, while CAI in the control plots revealed higher values. On June 11, on the other hand, both the 6-weekly watering treatment and the control plots were significantly different from the 3-weekly watering treatment, with lower NDVI and $\mathrm{NDVI}_{705}$, and higher CAI.

Table 1

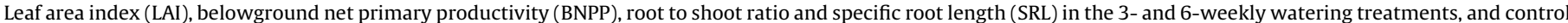

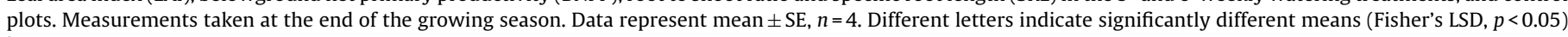
between treatments.

\begin{tabular}{|c|c|c|c|}
\hline & 3-weekly watering treatment & 6-weekly watering treatment & Control \\
\hline $\mathrm{LAI}\left(\mathrm{m}^{2} \mathrm{~m}^{-2}\right)$ & $1.04 \pm 0.110^{\mathrm{a}}$ & $1.03 \pm 0.152^{\mathrm{a}}$ & $0.42 \pm 0.060^{\mathrm{b}}$ \\
\hline $\operatorname{BNPP}\left(\mathrm{g} \mathrm{m}^{-2}\right)$ & $323 \pm 34.6^{\mathrm{a}}$ & $289 \pm 21.4^{\mathrm{a}}$ & $246 \pm 21.3^{\mathrm{a}}$ \\
\hline Root to shoot ratio & $1.98 \pm 0.337^{\mathrm{a}}$ & $1.83 \pm 0.333^{\mathrm{a}}$ & $3.99 \pm 0.418^{b}$ \\
\hline $\operatorname{SRL}\left(\mathrm{m} \mathrm{g}^{-1}\right)$ & $105 \pm 9.9^{\mathrm{ab}}$ & $124 \pm 5.5^{\mathrm{a}}$ & $92 \pm 5.2^{\mathrm{b}}$ \\
\hline
\end{tabular}




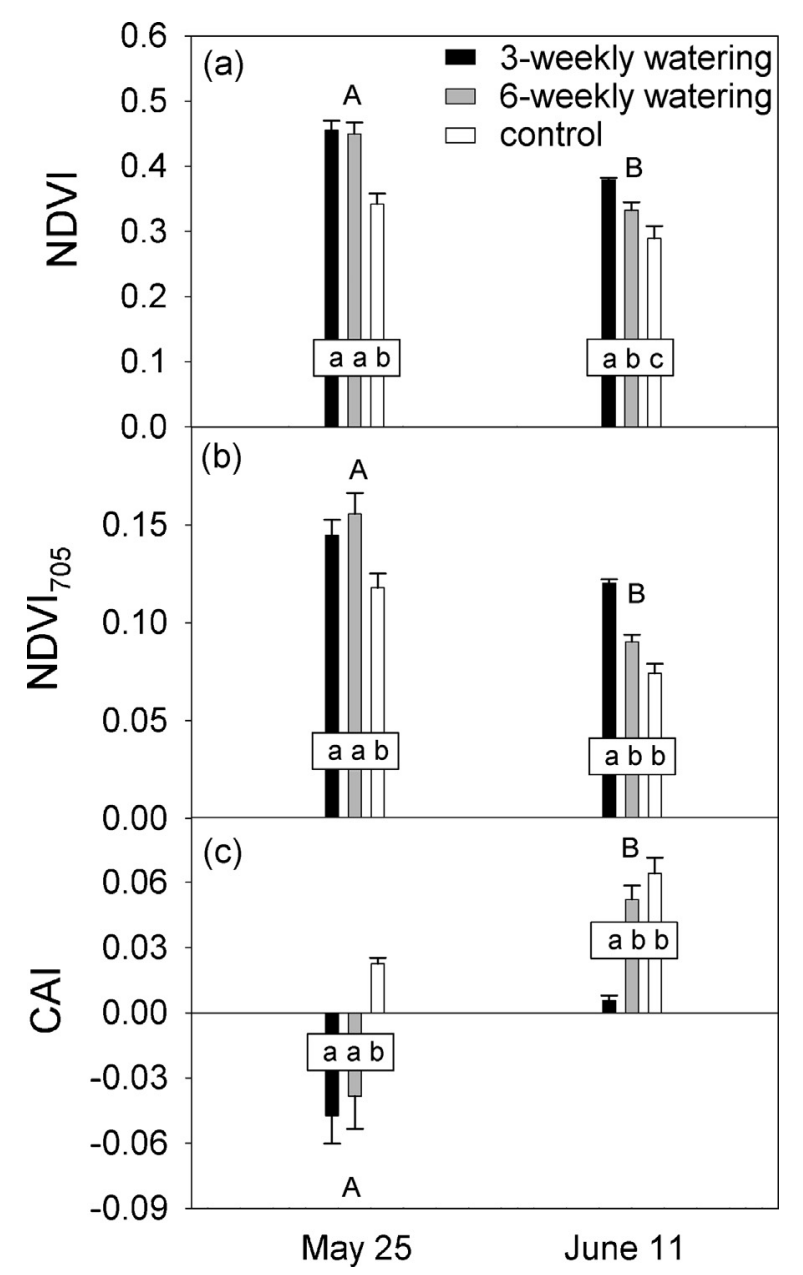

Fig. 5. (a) Normalised Difference Vegetation Index (NDVI), (b) Red Edge Normalised Difference Vegetation Index ( $\mathrm{NDVI}_{705}$ ), and (c) Cellulose Absorption Index (CAI) in the 3-weekly ( $\square$ ) and 6-weekly ( $\square$ ) watering treatments, and control plots ( $\square$ ). Bars show mean \pm SE, $n=4$. Different letters indicate significantly different means (Fisher's LSD, $p<0.05$ ) between date (capital letters) and treatment at each harvest (lower-case letters).

\subsection{Species composition}

Community structure, expressed as the relative abundance of the functional groups grasses, forbs and legumes, is shown in Fig. 6 . The vegetation in this montado understorey is dominated by forbs, which account on average for $66 \%$ of aboveground productivity (Fig. 6b). In February, Spergula arvensis and Rumex acetosella were the prominent forbs, accounting for $65 \%$ of forb biomass. In May, prominent forb species were Tolpis barbata, Tuberaria guttatta, Rumex acetosella and Bellardia trixago, these four species accounting for $87 \%$ of forb biomass. The average relative abundance of grasses (Fig. 6a) was $28 \%$, with Agrostis pourretii and Vulpia geniculata as prominent species. The relative abundance of grasses and forbs was not affected by the experimental watering treatments, and both functional groups showed little change in their relative abundance along the growing season. However, in the control plots, the contribution of grasses rapidly decreased between March and May, with a simultaneous increase in the relative abundance of forbs, resulting in significant differences between these functional group abundances in May, when comparing control plots with the two water manipulation treatments.

The relative abundance of legumes, with the prominent species being Ornithopus pinnatus, was low, and affected by treatment at all harvests. In the 3 -weekly watering treatment, relative

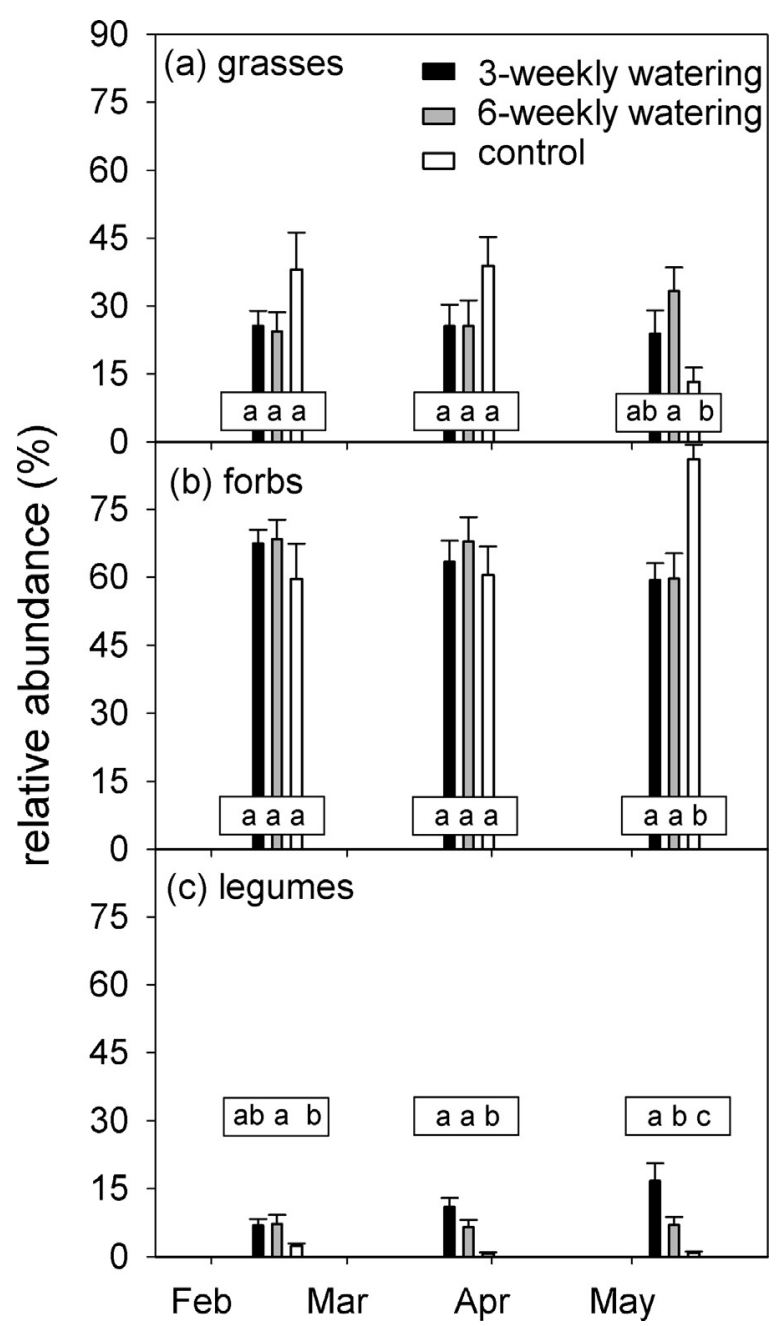

Fig. 6. Relative abundance of (a) grasses, (b) forbs and (c) legumes for three sequential harvests in the 3-weekly $(\boldsymbol{\square})$ and 6-weekly $(\square)$ watering treatments, and control plots $(\square)$. Data represent percentage biomass contribution to ANPP. Bars show mean \pm SE, $n=4$. Different letters indicate significantly different means (Fisher's LSD, $p<0.05$ ) between treatments at each harvest.

abundance of legumes along the growing season significantly increased ( $p=0.004$ ) from $7 \%$ to $17 \%$, while in the 6 -weekly watering treatment legume contribution did not change. In contrast, legume contribution to total biomass in the control plots along the growing season decreased to $<1 \%$ in May.

\subsection{N dynamics}

Tissue $\mathrm{N}$ concentration was significantly higher in legumes, as compared to the grasses and forbs (Fig. 7). No significant differences were found in tissue $\mathrm{N}$ in grasses, forbs or legumes between the 3-and 6-weekly watering treatments, with tissue $\mathrm{N}$ decreasing along the growing season in both treatments. In the control plots, however, tissue $\mathrm{N}$ in grasses and forbs did not change during the growing season. As a result, tissue $\mathrm{N}$ concentration in grasses and forbs in the control plots were significantly higher in May, as compared to the two water manipulation treatments (Fig. 7).

Changes in total herbage $\mathrm{N}$ along the growing season (Fig. 7d) followed the observed changes in ANPP (Fig. 4). Herbage N did not differ significantly between the 3- and 6-weekly watering treatment, and on average increased from 1.5 to $2.5 \mathrm{~g} \mathrm{~m}^{-2}$ between February and May, the period of active biomass development. However, herbage $\mathrm{N}$ in the control plots did not increase along the 

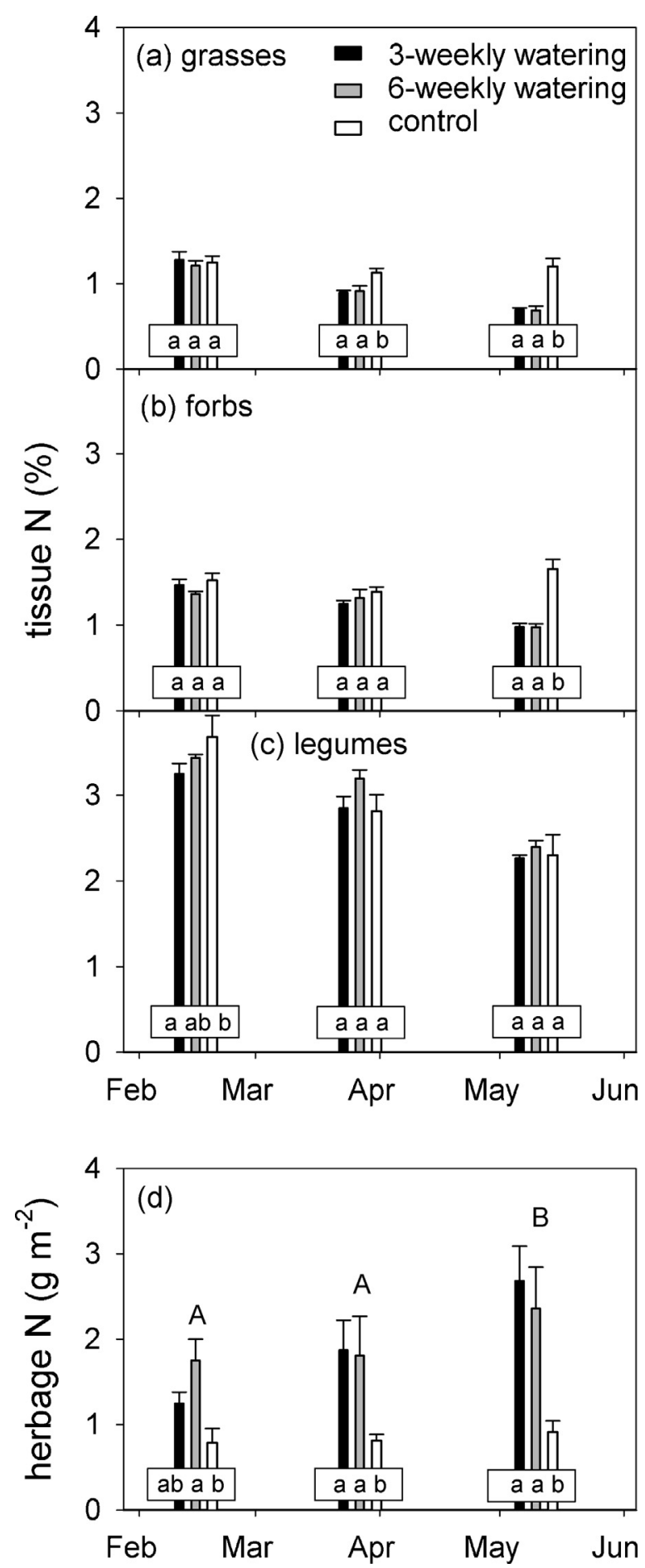

Fig. 7. $N$ concentration (\%) in aboveground biomass of (a) grasses, (b) forbs and (c) legumes, and (d) total herbage $\mathrm{N}$ content $\left(\mathrm{g} \mathrm{m}^{-2}\right)$ in aboveground vegetation for three sequential harvests in the 3-weekly ( $\square$ ) and 6-weekly ( $\square$ ) watering treatments, and control plots $(\square)$. Bars show mean \pm SE, $n=4$. Different letters indicate significantly different means (Fisher's LSD, $p<0.05$ ) between date (capital letters) and treatment at each harvest (lower-case letters).

growing season, and compared to the two water manipulation treatments, herbage $\mathrm{N}$ in the control plots was significantly lower in April and May (Fig. 7d).

Seasonal dynamics of soil inorganic N, extracted from the top $10 \mathrm{~cm}$ soil layer, are indicative of a nitrogen limited ecosystem, with low values of extractable $\mathrm{N}$ (Fig. 8). Most of the soil inorganic $\mathrm{N}$ was present as ammonium $\left(\mathrm{NH}_{4}{ }^{+}-\mathrm{N}\right)$, with nitrate $\left(\mathrm{NO}_{3}{ }^{-}-\mathrm{N}\right)$ only detectable in November (averaged $\mathrm{NO}_{3}{ }^{-}-\mathrm{N}$ of $0.3 \mu \mathrm{g} \mathrm{g}^{-1}$ ). Soil inorganic $\mathrm{N}$ dynamics were significantly affected by date $(p<0.001)$, with values ranging from 0.2 to $2.1 \mu \mathrm{gg}^{-1}$. In January and March soil $\mathrm{NH}_{4}{ }^{+}-\mathrm{N}$ in the control plots was significantly higher as compared to the two experimental watering treatments. However, with the exception of January 5, no significant differences were found between the 3 - and 6-weekly watering treatments. Irrigation resulted in a decrease in extractable soil $\mathrm{NH}_{4}{ }^{+}-\mathrm{N}$, as compared to concentrations prior to watering, this decrease being more pronounced in the 6-weekly watering treatment.

Although no $\mathrm{NO}_{3}{ }^{-}-\mathrm{N}$ was detected in the top $10 \mathrm{~cm}$ soil layer in any of the treatments from January onwards, ion-exchange resin capsules, giving a measure of plant available $\mathrm{N}$ over the growing season, showed that cumulative $\mathrm{NO}_{3}{ }^{-}-\mathrm{N}$ availability exceeded $\mathrm{NH}_{4}{ }^{+}-\mathrm{N}$ in all three treatments (Fig. 9). In addition, cumulative available $\mathrm{NO}_{3}{ }^{-} \mathrm{N}$, and as a consequence available total $\mathrm{N}$, in the control plots was significantly lower as compared to the two experimental watering treatments.

Analysis of pore water, collected in the 3- and 6-weekly watering treatments after irrigation in February, March and May at a depth of $30 \mathrm{~cm}$, revealed no $\mathrm{NH}_{4}{ }^{+}-\mathrm{N}$, while $\mathrm{NO}_{3}{ }^{-}-\mathrm{N}$ in March and May was below the detection limit of $<0.5 \mathrm{mgl}^{-1}$. However, on February 15, one day after irrigation, pore water $\mathrm{NO}_{3}{ }^{-} \mathrm{N}$ was $3.8 \pm 1.6$ and $3.3 \pm 0.2 \mathrm{mg} \mathrm{l}^{-1}$ in the 3 - and 6 -weekly watering treatments, respectively (results not shown).

\section{Discussion}

\subsection{Precipitation variability}

Our results showed that precipitation variability, with an increase of the dry period from three to six weeks, without changing total precipitation inputs, did not affect productivity of the herbaceous understorey vegetation. Contrary to our hypothesis, ANPP, BNPP, vegetation height and LAI were not significantly reduced in the 6-weekly watering treatment. In addition, no significant differences were observed in the root to shoot ratio and SRL between the 3- and 6-weekly watering treatments. Thus, although differences in temporal soil moisture dynamics between these two treatments were apparent, and more importantly, variability of SWC and the number of days with SWC below the wilting point was higher in the 6-weekly watering treatment, as compared to the 3-weekly watering treatment, this did not result in differences in productivity. This shows the resilience of the annual C3 species to variation in soil moisture, and indicates their ability to cope with irregular precipitation patterns through a high degree of phenotypic plasticity (Jump and Peñuelas, 2005; Miranda et al., 2009) and the possibility to employ strategies that improve water uptake and reduce water consumption (e.g. Moreno et al., 2008). This phenotypic adaptation to water stress was evident from data on leaf-level photosynthesis on May 6 on three prominent species, Tolpis barbata, Tuberaria guttatta and Rumex acetosella, which together account for $\sim 42 \%$ of ANPP (Table 2). With SWC in the 3- and 6- weekly watering treatment being $8.1 \%$ and $5.2 \%$, respectively, the latter value well below the wilting point, data showed that all three species were able to maintain photosynthesis, with lower stomatal conductance and transpiration in the 6-weekly watering treatment in Tuberaria and Rumex indicating an increased water-use efficiency.

Peak ANPP, occurring in May 2012, gave values of 241 and $235 \mathrm{~g} \mathrm{~m}^{-2}$ in the 3- and 6-weekly watering treatment, respectively. Previous single-year studies on peak ANPP of the herbaceous understorey vegetation in evergreen woodlands in Iberia report values of $195-250 \mathrm{~g} \mathrm{~m}^{-2}$ (Castro and Freitas, 2009; Hussain et al., 2009; Li et al., 2008). However, Vázquez-de-Aldana et al. (2008) reported large interannual variations of ANPP over a 20 -year period, 


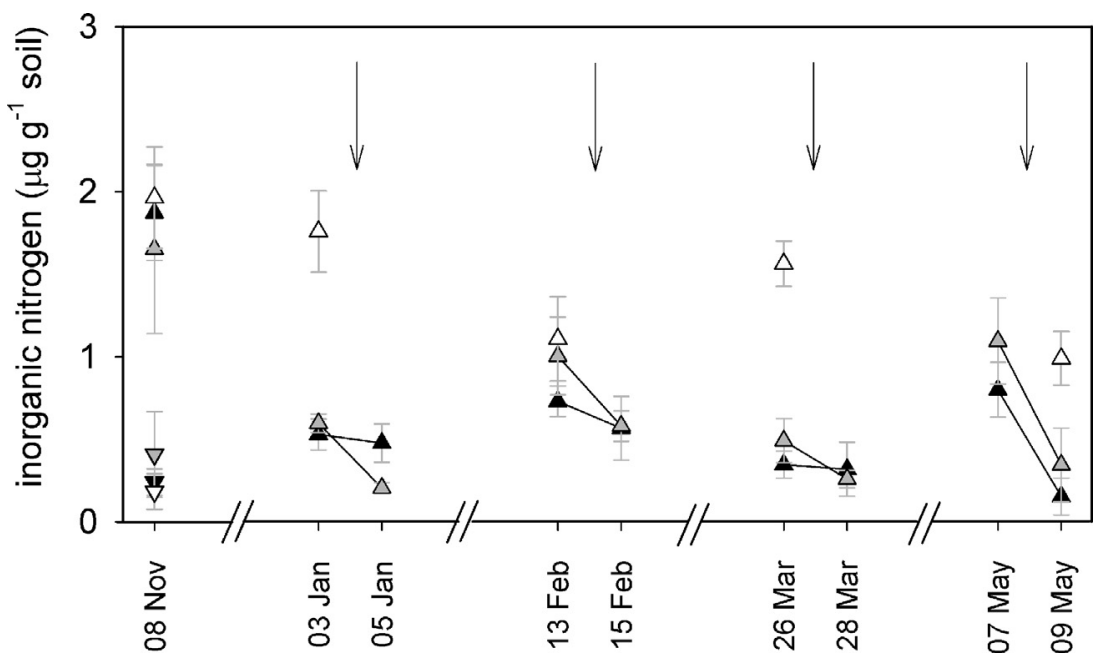

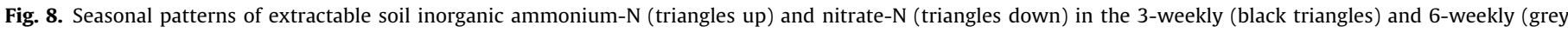
triangles) watering treatments, and control plots (white triangles). Data represent mean $\pm \mathrm{SE}, n=4$. Arrows indicate timing of watering events.

values ranging from 50 to $419 \mathrm{~g} \mathrm{~m}^{-2}$, with ANPP correlated with annual precipitation. Similarly, Otieno et al. (2011) reported peak ANPP of $123-247 \mathrm{~g} \mathrm{~m}^{-2}$ for the period of 2004-2006, with a positive ANPP-precipitation relationship. Peak ANPP in our study site in May 2011 (Jongen et al., 2013b), with vegetation subjected to a dry period of three weeks, was $409 \mathrm{~g} \mathrm{~m}^{-2}$. The substantially lower productivity in 2012 can partly be explained by the late onset of autumn precipitation, effectively reducing the length of the growing season, with consequences for ANPP at peak biomass, as has been previously reported in Mediterranean grasslands (Jongen et al., 2011; Ma et al., 2007). In addition, the lower soil inorganic $\mathrm{N}$ concentrations in 2012, with maximum values in the period of January to May of $\sim 1 \mu \mathrm{gg}^{-1}$, as compared to maximum soil inorganic $\mathrm{N}$ of $6.5 \mu \mathrm{g} \mathrm{g}^{-1}$ in 2011 (Jongen et al., 2013a) resulted in more severe nitrogen limitation.

In a mesic grassland, increasing precipitation variability has previously been shown to decrease ANPP, simultaneously enhancing species diversity (Knapp et al., 2002), the latter possibly being an indirect response to the reduced productivity. However, for a Mediterranean grassland, Miranda et al. (2009) reported no effects of precipitation variability on productivity and species diversity. Similarly, a previous study on the effects of precipitation variability on ecosystem processes in the herbaceous understorey in a Mediterranean oak woodland, with the dry period extended from one to three weeks, showed no significant effect on productivity and community structure (Jongen et al., 2013b). In our study, altering precipitation pattern did not affect overall community structure, although legumes exhibited higher sensitivity to low soil water availability, as previously reported in Jongen et al. (2013b). With legumes only accounting for a small percentage of total ANPP,

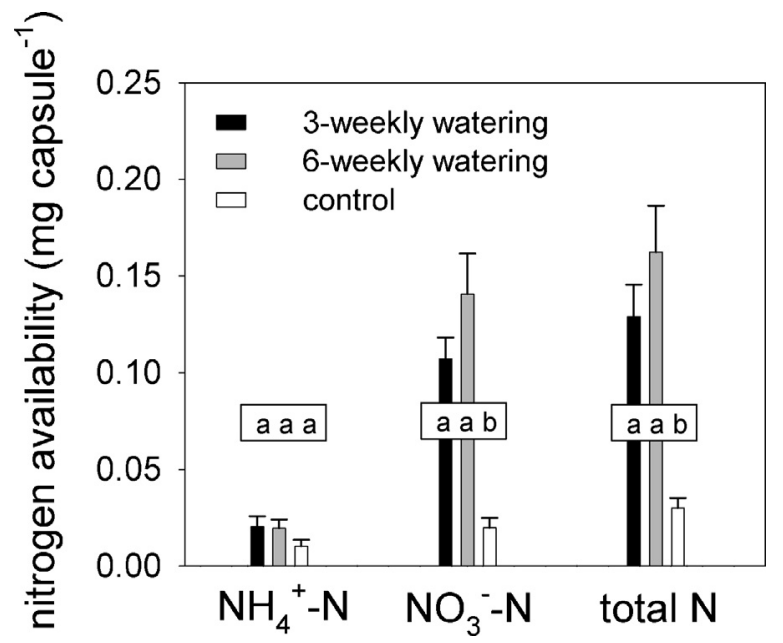

Fig. 9. Resin $\mathrm{N}$ availability for the October to June period in the 3-weekly ( $\mathbf{\square})$ and 6-weekly $(\square)$ watering treatment, and control plots ( $\square$ ). Data represent mean \pm SE, $n=4$.

this did not affect productivity, but might have implications for soil nitrogen supply.

Leaf senescence, being an integral part of plant development, is a genetically controlled process, regulated by a variety of autonomous and environmental factors (Buchanan-Wollaston, 1997), the major environmental cue being limited water availability (Gan and Amasino, 1997). In our study, precipitation pattern did affect rate of senescence, as shown by the significant differences in

Table 2

Leaf-level photosynthesis $(A)$, stomatal conductance $\left(g_{s}\right)$ and transpiration $(E)$ for Tolpis barbata, Tuberaria guttatta and Rumex acetosella in the 3-weekly (3) and 6-weekly (6) watering treatments.

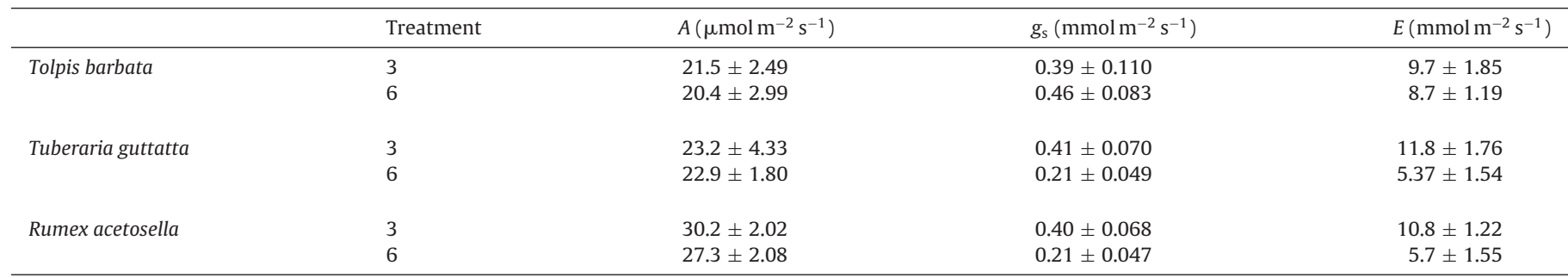

Leaf-level gas exchange measurements were performed on May 6, immediately prior to irrigation, using a LI-6400 portable photosynthesis system (Li-Cor Inc., Lincoln, NE, USA) at ambient light $\left(1659 \pm 89.2 \mu \mathrm{mol} \mathrm{m}^{-2} \mathrm{~s}^{-1}\right)$. Data represent mean $\pm \mathrm{SE}, n=4$. 
all three vegetation indices (NDVI, $\mathrm{NDVI}_{705}$ and $\mathrm{CAI}$ ) between the 3 - and 6-weekly watering treatment on June 11 , with no difference found on May 25. The accelerated senescence in the 6-weekly watering treatment resulted from the decreasing soil moisture, with SWC being below the wilting point from May 26 onwards. Irrigation on May 29 in the 3-weekly watering treatment alleviated water stress, thereby reducing vegetation senescence. As the timing of senescence is of primary importance for plant reproductive success (e.g. Lim et al., 2007), altered precipitation regimes might have consequences for seed bank regeneration, consequently affecting ecosystem productivity and community structure in subsequent years.

Consistent with the lack of productivity responses to altered precipitation regime, no differences were observed in $\mathrm{N}$ dynamics between the 3- and 6-weekly watering treatment, neither in soil inorganic $\mathrm{N}$, soil $\mathrm{N}$ availability, \% tissue $\mathrm{N}$ nor in herbage $\mathrm{N}$. Soil inorganic $\mathrm{N}$ was very low, indicating that $\mathrm{N}$ was a limiting factor for biomass development, with maximum values in the experimental watering treatments in the period from January to May of $\sim 1 \mu \mathrm{g} \mathrm{g}^{-1}$, with $\mathrm{NH}_{4}{ }^{+}$-N being the only inorganic $\mathrm{N}$ species detected in the top $10 \mathrm{~cm}$ soil. The absence of extractable $\mathrm{NO}_{3}{ }^{-}-\mathrm{N}$ in soil samples during the growing season of the herbaceous understorey was likely caused by the rapid plant uptake of this ion, preventing $\mathrm{NO}_{3}{ }^{-} \mathrm{N}$ accumulating in the soil. A complete uptake of $\mathrm{NO}_{3}{ }^{-}-\mathrm{N}$ is consistent with the findings that resin capsules did reveal $\mathrm{NO}_{3}{ }^{-}-\mathrm{N}$ availability. Moreover, in both treatments, resin capsules showed a higher cumulative availability of soil $\mathrm{NO}_{3}{ }^{-} \mathrm{N}$, as compared to $\mathrm{NH}_{4}{ }^{+}-\mathrm{N}$. Further evidence that sward development was limited by nitrogen can be found in the decline of \% tissue $\mathrm{N}$ in both the 3- and 6 -weekly watering treatments along the growing season, a common finding in nitrogen-limited ecosystems (Goedhart et al., 2010; Sudderth et al., 2012).

Although numerous studies report on the soil moisture dependence of microbial activity (e.g. Correia et al., 2012; Dijkstra et al., 2012), which strongly influences soil N availability (Araya et al., 2012; Borken and Matzner, 2009), only limited information is available on the effects of precipitation variability, without altering total annual precipitation inputs, on soil inorganic $\mathrm{N}$. In a mixed grass prairie, Heisler-White et al. (2009) reported no difference in soil $\mathrm{N}$ availability in response to larger, less frequent precipitation events, which is in agreement with our results (Fig. 9), with no significant differences in soil $\mathrm{NH}_{4}{ }^{+}-\mathrm{N}$ and $\mathrm{NO}_{3}{ }^{-}-\mathrm{N}$ availability between the 3and 6-weekly watering treatments.

Increasing precipitation variability, without altering total water inputs, has previously been shown to increase nitrate losses through leaching (Jongen et al., 2013a; Yahdjian and Sala, 2010). In our study, pore water collected at a depth of $30 \mathrm{~cm}$ after large precipitation events did not reveal any $\mathrm{NO}_{3}{ }^{-}-\mathrm{N}$ in March and May, consistent with the lack of $\mathrm{NO}_{3}{ }^{-}-\mathrm{N}$ in soil samples. Only in February, small concentrations of $\mathrm{NO}_{3}{ }^{-}-\mathrm{N}$ were detected in pore water samples, although no $\mathrm{NO}_{3}{ }^{-}-\mathrm{N}$ was found in the top $10 \mathrm{~cm}$ soil layer, the latter finding being explained by plant uptake. Thus the $\mathrm{NO}_{3}{ }^{-}-\mathrm{N}$ in pore water probably originated from the $10-30 \mathrm{~cm}$ soil profile, as the understorey plants only have a shallow root system this early in the growing season.

\subsection{Drought}

Drought is a natural phenomenon, occurring when water availability is significantly below normal levels over a long period and water supply cannot meet the demand (Vicente-Serrano et al., 2012). Drought time-scales, referring to the time lag existing between the start of a water deficiency and impact detection, for example a decrease of ANPP, play a key role in determining the sensitivity of a given ecosystem to drought. Several studies have shown species specific differences in the time-scale response to drought, i.e. species differ regarding their drought tolerance (Craine et al., 2013; Godfree et al., 2011; Valladares and SánchezGómez, 2006). In addition, the response of vegetation to drought has been shown to depend on biome characteristic time-scales, with the vegetation in semi-arid ecosystems tending to respond to drought at longer time-scales, as compared to arid and humid biomes (Vicente-Serrano et al., 2012).

Wintertime droughts are increasingly common in the Mediterranean region (Hoerling et al., 2012). The last major drought affecting the Iberian Peninsula occurred in 2004-2005, with severe negative impacts on vegetation growth and consequently on agricultural production (Garcia-Herrera et al., 2007). During our study period (2011-2012), yet another extreme wintertime drought occurred in Portugal, with vegetation only receiving a mere $10 \mathrm{~mm}$ of precipitation in the period of mid December until the end of March. This resulted in the control plots being subjected to prolonged drought and reduced precipitation, as compared to the two experimental watering treatments, with soil moisture below the wilting point by the end of February, $\sim 10$ weeks after the last substantial precipitation. The negative impacts of this drought on the control plots were not only evident from the low productivity, as compared to the two experimental watering treatments, but also as compared with ANPP in previous years. More so, the lack of a significant increase in ANPP between February and May indicates drought impact. Additional drought effects were evident from the significantly lower LAI and higher root to shoot ratio, as compared to the two watering treatments. Increased root to shoot ratios in response to drought indicate changes in the source sink relationship, with increased carbon allocation to belowground processes (e.g. Gilgen and Buchmann, 2009; Kahmen et al., 2005). Although drought obviously limited productivity in the control plots, we have to consider the possibility of a positive shelter effect (e.g. reduced radiation stress and/or decreased ratio of direct-diffuse radiation) in the two experimental watering treatments. This may have enhanced productivity in these treatments, as in February, with no water limitation, ANPP in the 6-weekly watering treatment was already significantly higher as compared to the control plots.

The change in community structure occurring after the end of the drought period, with the relative abundance of grasses and legumes decreasing, while forbs increased, indicated speciesspecific sensitivity to drought. Previous studies have reported changes in community structure and composition with drought (Evans et al., 2011; Kennedy et al., 2003; Weaver et al., 1935). In Mediterranean grasslands, early precipitation followed by a long dry period, favoured drought-tolerant species and led to the death of annual grass and legume species (Rossiter, 1966). In our study, point quadrat analysis (results not shown) and personal observations showed that at the end of March, virtually all grasses and legumes in the control plots had died. In contrast, the prominent forb species, Tolpis barbata, Tuberaria guttatta and Rumex acetosella, were able to withstand the severe drought conditions. This agrees with previous studies reporting the resistance of forb species to drought, this resistance being closely related with root extent (Weaver et al., 1935). Precipitation in April enabled grasses to regenerate and flower, explaining the rapid increase in vegetation height in the control plots towards the end of the growing season. After the last substantial natural precipitation on May 7 $(19 \mathrm{~mm})$, SWC in the control plots rapidly decreased, being below the wilting point from May 23 onwards. This resulted in accelerated senescence in the control plots, as compared to the two experimental watering treatments, with differences in all three vegetation indices already apparent on May 25.

Microbial processes in the soil, such as decomposition of plant litter and soil organic matter into plant-available nitrogen, are strongly regulated by soil moisture (e.g. Brady and Weil, 2002; Paul 
and Clark, 1996), with nitrification being more sensitive to drought stress than ammonification (Chen et al., 2011; Paul and Clark, 1996). Indeed, in our study, low soil moisture in the control plots affected nitrogen availability, this effect being more pronounced for $\mathrm{NO}_{3}{ }^{-}-$ $\mathrm{N}$, with cumulative availability of this ion over the growing season being reduced by $\sim 80 \%$ as compared to the two experimental watering treatments. We suspect a strong drought induced impairment of the conversion of ammonium to nitrate, which can explain the finding that soil $\mathrm{NH}_{4}{ }^{+}-\mathrm{N}$ in control plots was higher, as compared to the other two treatments. The little $\mathrm{NO}_{3}{ }^{-} \mathrm{N}$ formed would have rapidly been taken up by plants, explaining the absence of $\mathrm{NO}_{3}{ }^{-}-\mathrm{N}$ in the soil. Thus, in addition to the obvious water limitation on productivity in February and March, low soil moisture in the control plots affected nitrogen availability. This probably resulted in $\mathrm{N}$ limitation in April and May, when natural precipitation reduced water stress. However, constant tissue $\% \mathrm{~N}$ in the control plots over the growing season demonstrated that, in contrast to the watering treatments, productivity was predominantly water limited.

\section{Conclusions}

Future climate change scenarios for the Iberian Peninsula predict an increased temporal variability in precipitation regimes, with a higher frequency of extreme rainfall events, a lower frequency of rainfall days and longer intervening dry periods. This study demonstrates the high resilience of the herbaceous understorey, in a typical Mediterranean oak woodland, to increased precipitation variability within the growing season, with no significant differences in productivity, community structure and soil $\mathrm{N}$ dynamics between the 3- and 6-weekly watering treatments. Our results support the idea that the herbaceous C3 plants, in addition to adjusting their life-cycle to the seasonal water availability through avoidance of the dry hot summer period, are capable of coping with increases in the length of the dry period during the growing season, indicating a high degree of phenotypic and physiological adaptability. However, vegetation in the 6-weekly watering treatment was shown to shorten its life cycle resulting in earlier senescence, potentially having consequences for reproductive success. Although resilient to low soil moisture, the vegetation in the experimental watering treatments was found to be strongly nitrogen limited.

In comparison to understorey vegetation subjected to precipitation manipulation, control plots experienced a severe wintertime drought, with the length of the dry period increased to $\sim 15$ weeks, and soil moisture being below the wilting point by the end of February, $\sim 10$ weeks after the last substantial natural precipitation in December. This wintertime drought significantly reduced productivity, with the vegetation predominantly water limited and comparatively less limited by soil nitrogen, as compared to the watering treatments. In addition, drought significantly altered plant community structure, with forbs being more resistant to drought as compared to legumes and grasses.

In short, although the understorey vegetation was resilient to changes in precipitation variability, with the intervening dry period extended to six weeks, long drought periods, as experienced by the control plots, exerted highly negative effects. With semi-arid ecosystems tending to respond to drought at long time-scales, our results showed that the understorey vegetation was not able to buffer the drought effects through adaptive strategies when the length of the dry period exceeded 10 weeks.

Our results highlight the necessity for further studies investigating how climate change will influence the co-limitation of water and nitrogen availability, which in turn might affect plant productivity in Mediterranean ecosystems. Answers are needed to develop appropriate land management strategies and mitigation approaches.

\section{Acknowledgements}

The authors gratefully acknowledge the financial support of FCT (Fundação para a Ciência e Tecnologia), through the project PTDC/CLI/79662/2011 and through postdoctoral fellowships to Marjan Jongen (SFRH/BPD/79662/2011), David Fangueiro (SFRH/BPD/84229/2012) and Sofia Cerasoli (SFRH/BPD/28684/2006). The authors wish to thank António Gonçalves Ferreira for providing the field site at Machoqueira do Grou, the staff of Machoqueira do Grou, especially Mr. Pirra, for continuous support to the work, Xavier Lecomte, Filipe Costa e Silva, Joaquim Mendes, Francesco Minunno and Alexandra Correia for assisting with the construction of the rain-out shelters, Florian Ulm for valuable help with the fieldwork, Prof. Fernando Monteiro for the measurements of wilting point, Elsa Breia for support in the laboratory, and Peter Fay for suggestions on the manuscript.

\section{References}

Aguilar, J., Evans, R., Daughtry, C.S.T., 2012. Performance assessment of the cellulose absorption index method for estimating crop residue cover. J. Soil Water Conserv. 67, 202-210.

Aires, L.M.I., Pio, C.A., Pereira, J.S., 2008. Carbon dioxide exchange above a Mediterranean C3/C4 grassland during two climatologically contrasting years. Glob. Change Biol. 14, 539-555.

Araya, Y.N., Gowing, D.J., Dise, N., 2012. Does soil nitrogen availability mediate the response of grassland composition to water regime? J. Veg. Sci. 24, 506-517.

Austin, A.T., Yahdjian, L., Stark, J.M., Belnap, J., Porporato, A., Norton, U., Ravetta, D.A., Schaeffer, S.M., 2004. Water pulses and biogeochemical cycles in arid and semiarid ecosystems. Oecologia 141, 221-235.

Borken, W., Matzner, E., 2009. Reappraisal of drying and wetting effects on C and N mineralization and fluxes in soils. Glob. Change Biol. 15, 808-824.

Brady, N.C., Weil, R.R., 2002. The Nature and Properties of Soils. Prentice Hall, Upper Saddle River, NJ, USA.

Buchanan-Wollaston, V., 1997. The molecular biology of leaf senescence. J. Exp. Bot. 48, 181-199.

Bugalho, M.N., Caldeira, M.C., Pereira, J.S., Aronson, J., Pausas, J.G., 2011. Mediterranean cork oak savannas require human use to sustain biodiversity and ecosystem services. Front. Ecol. Environ. 9, 278-286.

Castro, C., Freitas, H., 2009. Above-ground biomass and productivity in the Montado: from herbaceous to shrub dominated communities. J. Arid Environ. 73 , 506-511.

Chabrillat, S., 2006. Land degradation indicators: spectral indices. Ann. Arid Zone 45, 331-354.

Chen, Y.-T., Borken, W., Stange, C.F., Matzner, E., 2011. Effects of decreasing water potential on gross ammonification and nitrification in an acid coniferous forest soil. Soil Biol. Biochem. 43, 333-338.

Cherwin, K., Knapp, A.K., 2012. Unexpected patterns of sensitivity to drought in three semi-arid grasslands. Oecologia 169, 845-852.

Christensen, J.H., Hewitson, B., Busuioc, A., Chen, A., Gao, X., Held, I., Jones, R., Kolli, R.K., Kwon, W.-T., Laprise, R., Magaña Rueda, V., Mearns, L., Menéndez, C.G., Räisänen, J., Rinke, A., Sarr, A., Whetton, P., 2007. Regional climate projections. In: Solomon, S., Qin, D., Manning, M., Chen, Z., Marquis, M., Averyt, K.B., Tignor, M. Miller, H.L. (Eds.), Climate Change 2007: The Physical Science Basis. Contribution of Working Group I to the Fourth Assessment Report of the Intergovernmental Panel on Climate Change (IPCC). Cambridge University Press, Cambridge, UK, pp. $847-940$

Correia, A.C., Minunno, F., Caldeira, M.C., Banza, J., Mateus, J., Carneiro, M., Wingate, L., Shvaleva, A., Ramos, A., Jongen, M., Bugalho, M.N., Nogueira, C., Lecomte, X., Pereira, J.S., 2012. Soil water availability strongly modulates soil $\mathrm{CO}_{2}$ efflux in different Mediterranean ecosystems: Model calibration using the Bayesian approach. Agr. Ecosyst. Environ. 161, 88-100.

Cossani, C.M., Slafer, G.A., Savin, R., 2010. Co-limitation of nitrogen and water, and yield and resource-use efficiencies of wheat and barley. Crop Pasture Sci. 61 $844-851$.

Craine, J.M., Ocheltree, T.W., Nippert, J.B., Towne, E.G., Skibbe, A.M., Kembel, S.W., Fargione, J.E., 2013. Global diversity of drought tolerance and grassland climatechange resilience. Nature Clim. Change 3,63-67.

Crespo, D., 2010. Species diversity: David Crespo takes C3 pastures the next step to boost soil carbon. Aust. Farm J. 20, 44-47.

Di Bella, C.M., Paruelo, J.M., Becerra, J.E., Bacour, C., Baret, F., 2004. Effect of senescent leaves on NDVI-based estimates of fAPAR: experimental and modelling evidences. Int. J. Remote Sens. 25, 5415-5427.

Dijkstra, F.A., Augustine, D.J., Brewer, P., von Fischer, J.C., 2012. Nitrogen cycling and water pulses in semiarid grasslands: are microbial and plant processes temporally asynchronus? Oecologia 170, 799-808.

Dubbert, M., Cuntz, M., Piayda, A., Máguas, C., Werner, C., 2013. Partitioning evapotranspiration-testing the Craig and Gordon model with field measurements of oxygen isotope ratios of evaporative fluxes. J. Hydrol. 496, 142-153. 
Easterling, D.R., Evans, J.L., Groisman, P.Y., Karl, T.R., Kunkel, K.E., Ambenje, P., 2000. Observed variability and trends in extreme climate events: a brief review. Bull. Am. Meteorol. Soc. 81, 417-442.

Epstein, H., Paruelo, J., Piñeiro, G., Lauenroth, W., Burke, I., Barrett, J., 2005. Co-limitation of primary productivity by water and nitrogen along regional gradients of mean annual precipitation. Geophys. Res. Abstr. 7, 08078.

Evans, S.E., Byrne, K.M., Lauenroth, W.K., Burke, I.C., 2011. Defining the limit to resistance in a drought-tolerant grassland: long-term severe drought significantly reduces the dominant species and increases ruderals. J. Ecol. 99, 1500-1507.

FAO, 2006. World Reference Base for Soil Resources: World Soil Resource Report No. 103. FAO, Rome, Italy.

Fay, P.A., Carlisle, J.D., Knapp, A.K., Blair, J.M., Collins, S.L., 2003. Productivity responses to altered rainfall patterns in a C4-dominated grassland. Oecologia $137,245-251$.

Fay, P.A., Kaufman, D.M., Nippert, J.B., Carlisle, J.D., Harper, C.W., 2008. Changes in grassland ecosystem function due to extreme rainfall events: implications for responses to climate change. Glob. Change Biol. 14, 1600-1608.

Gallego, M.C., Trigo, R.M., Vaquero, J.M., Brunet, M., García, J.A., Sigró, J., Valente, M.A., 2011. Trends in frequency indices of daily precipitation over the Iberian Peninsula during the last century. J. Geophys. Res. 116, D02109.

Gamon, J.A., Field, C.B., Goulden, M.L., Griffin, K.L., Hartley, A.E., Joel, G., Peñuelas, J., Valentini, R., 1995. Relationships between NDVI, canopy structure, and photosynthesis in three Californian vegetation types. Ecol. Appl. 5, 28-41.

Gan, S., Amasino, R.M., 1997. Making sense of senescence. Plant Physiol. 113, 313-319.

Garcia-Herrera, R., Paredes, D., Trigo, R.M., Trigo, I.F., Hernandez, E., Barriopedro, D., Mendes, M.A., 2007. The outstanding 2004/05 drought in the Iberian Peninsula: associated atmospheric circulation. J. Hydrometeorol. 8, 483-498.

Gilgen, A.K., Buchmann, N., 2009. Response of temperate grasslands at different altitudes to simulated summer drought differed but scaled with annual precipitation. Biogeosciences 6, 2525-2539.

Giorgi, F., Lionello, P., 2008. Climate change projections for the Mediterranean region. Glob. Planet. Change 63, 90-104.

Godfree, R., Lepschi, B., Reside, A., Bolger, T., Robertson, B., Marshall, D., Carnegie, M., 2011. Multiscale topoedaphic heterogeneity increases resilience and resistance of a dominant grassland species to extreme drought and climate change. Glob. Change Biol. 17, 943-958.

Goedhart, C.M., Pataki, D.E., Billings, S.A., 2010. Seasonal variations in plant nitrogen relations and photosynthesis along a grassland to shrubland gradient in Owens Valley, California. Plant Soil 327, 213-223.

Goudriaan, J., van Laar, H.H., 1994. Modelling Potential Crop Growth Processes. Kluwer Academic Publishers, Dordrecht, The Netherlands.

Grime, J.P., Brown, V.K., Thompson, K., Masters, G.J., Hillier, S.H., Clarke, I.P., Askew, A.P., Corker, D., Kielty, J.P., 2000. The response of two contrasting limestone grasslands to simulated climate change. Science 289, 762-765.

Harper, C.W., Blair, J.M., Fay, P.A., Knapp, A.K., Carlisle, J.D., 2005. Increased rainfall variability and reduced rainfall amount decreases soil $\mathrm{CO}_{2}$ flux in a grassland ecosystem. Glob. Change Biol. 11, 322-334.

Heisler-White, J.L., Blair, J.M., Kelly, E.F., Harmoney, K., Knapp, A.K., 2009. Contingent productivity responses to more extreme rainfall regimes across a grassland biome. Glob. Change Biol. 15, 2894-2904.

Hoerling, M., Eischeid, J., Perlwitz, J., Quan, X., Zhang, T., Pegion, P., 2012. On the increased frequency of Mediterranean drought. J. Climate 25, 2146-2161.

Houba, V.J., van der Lee, J.J., Novozamsky, I., Walinga, I., 1989. Soil and Plant Analysis Part 5-Soil Analysis Procedures. Wageningen Agricultural University, Wageningen, The Netherlands.

Hussain, M.Z., Otieno, D., Mirzae, H., Li, Y.L., Schmidt, M.W.T., Siebke, L., Foken, T., Ribeiro, N.A., Pereira, J.S., Tenhunen, J.D., 2009. $\mathrm{CO}_{2}$ exchange and biomass development of the herbaceous vegetation in the Portuguese montado ecosystem during spring. Agr. Ecosyst. Environ 132, 143-152.

Jongen, M., Lecomte, X., Unger, S., Fangueiro, D., Pereira, J.S., 2013a. Precipitation variability does not affect soil respiration and nitrogen dynamics in the understorey of a Mediterranean oak woodland. Plant Soil, http://dx.doi.org/10.1007/s11104-013-1728-7.

Jongen, M., Lecomte, X., Unger, S., Pintó-Marijuan, M., Pereira, J.S., 2013b. The impact of changes in the timing of precipitation on the herbaceous understorey of Mediterranean oak woodlands. Agr. Forest Meteorol. 171-172, 163-173.

Jongen, M., Pereira, J.S., Aires, L.M., Pio, C.A., 2011. The effects of drought and timing of precipitation on the inter-annual variation in ecosystem-atmosphere exchange in a Mediterranean grassland. Agr. Forest Meteorol. 151, 595-606.

Jump, A.S., Peñuelas, J., 2005. Running to stand still: adaptation and the response of plants to rapid climate change. Ecol. Lett. 8, 1010-1020.

Kahmen, A., Perner, J., Buchmann, N., 2005. Diversity dependent productivity in semi-natural grasslands following climate perturbations. Funct. Ecol. 19, 594-601.

Kelley, C., Ting, M., Seager, R., Kushnir, Y., 2012. Mediterranean precipitation climatology, seasonal cycle, and trend as simulated by CMIP5. Geophys. Res. Lett. 39, L21703.

Kennedy, A.D., Biggs, H., Zambatis, N., 2003. Relationship between grass species richness and ecosystem stability in Kruger National Park, South Africa. Afr. J. Ecol. 41, 131-140.

Knapp, A.K., Fay, P.A., Blair, J.M., Collins, S.L., Smith, M.D., Carlisle, J.D., Harper, C.W., Danner, B.T., Lett, M.S., McCarron, J.K., 2002. Rainfall variability, carbon cycling, and plant species diversity in a mesic grassland. Science 298, 2202-2205.

Li, Y.L., Tenhunen, J., Mirzaei, H., Hussain, M.Z., Siebicke, L., Foken, T., Otieno, D., Schmidt, M., Ribeiro, N., Aires, L., Pio, C., Banza, J., Pereira, J.S., 2008. Assessment and up-scaling of $\mathrm{CO}_{2}$ exchange by patches of the herbaceous vegetation mosaic in a Portuguese cork oak woodland. Agr. Forest Meteorol. 148, 1318-1331.

Lim, P.O., Kim, H.J., Nam, H.G., 2007. Leaf senescence. Annu. Rev. Plant Biol. 58, $115-136$.

Luterbacher, J., Xoplaki, E., Casty, C., Wanner, H., Pauling, A., Küttel, M., Rutishauser, T., Brönnimann, S., Fischer, E., Fleitmann, D., Gonzalez-Rouco, F.J., GarcíaHerrera, R., Barriendos, M., Rodrigo, F., Gonzalez-Hidalgo, J.C., Saz, M.A., Gimeno, L., Ribera, P., Brunet, M., Paeth, H., Rimbu, N., Felis, T., Jacobeit, J., Dünkeloh, A., Zorita, E., Guiot, J., Türkes, M., Alcoforado, M.J., Trigo, R., Wheeler, D., Tett, S., Mann, M.E., Touchan, R., Shindell, D.T., Silenzi, S., Montagna, P., Camuffo, D., Mariotti, A., Nanni, T., Brunetti, M., Maugeri, M., Zerefos, C., De Zolt, S., Lionello, P., Nunes, M.F., Rath, V., Beltrami, H., Garnier, E., Ladurie, E.L.R., 2006. Mediterranean climate variability over the last centuries; a review. In: Lionello, P., Malanotte-Rizzoli, P., Boscolo, R. (Eds.), The Mediterranean Climate: An Overview of the Main Characteristics and Issues. Elsevier, Amsterdam, The Netherlands, pp. 27-148.

Ma, S., Baldocchi, D.D., Xu, L., Hehn, T., 2007. Inter-annual variability in carbon dioxide exchange of an oak/grass savanna and open grassland in California. Agr. Forest Meteorol. 147, 157-171.

Miranda, J.D., Padilla, F.M., Lázaro, R., Pugnaire, F.I., 2009. Do changes in rainfall patterns affect semiarid annual plant communities? J. Veg. Sci. 20, 269-276.

Moreno, M., Gulías, J., Lazaridou, M., Medrano, H., Cifre, J., 2008. Ecophysiological strategies to overcome water deficit in herbaceous species under Mediterranean conditions. Opt. Medit. 79, 247-256.

Moreno Marcos, G., Obrador, J.J., García, E., Cubera, E., Montero, M.J., Pulido, F., Dupraz, C., 2007. Driving competitive and facilitative interactions in oak dehesas through management practices. Agroforest. Syst. 70, 25-40.

Nagler, P.L., Inoue, Y., Glenn, E.P., Russ, A.L., Daughtry, C.S.T., 2003. Cellulose absorption index (CAI) to quantify mixed soil-plant litter scenes. Remote Sens. Environ. 87, 310-325.

Nippert, J.B., Knapp, A.K., Briggs, J.M., 2006. Intra-annual rainfall variability and grassland productivity: can the past predict the future? Plant Ecol. 184, 65-74.

Otieno, D.O., Mirzaei, H., Hussain, M.Z., Li, Y.L., Schmidt, M.W.T., Wartinger, M., Jung, E., Ribeiro, N., Pereira, J.S., Tenhunen, J., 2011. Herbaceous layer development during spring does not deplete soil nitrogen in the Portuguese montado. J. Arid Environ. 75, 231-238.

Paço, T.A., David, T.S., Henriques, M.O., Pereira, J.S., Valente, F., Banza, J., Pereira, F.L., Pinto, C., David, J.S., 2009. Evapotranspiration from a Mediterranean evergreen oak savannah: the role of trees and pasture. J. Hydrol. 369, 98-106.

Paul, E.A., Clark, F.E., 1996. Soil Microbiology and Biochemistry. Academic Press, San Diego, CA, USA.

Pereira, J.S., Mateus, J.A., Aires, L.M., Pita, G., Pio, C., David, J.S., Andrade, V., Banza, J., David, T.S., Paço, T.A., Rodrigues, A., 2007. Net ecosystem carbon exchange in three contrasting Mediterranean ecosystems-the effect of drought. Biogeosciences 4, 791-802

Pires, V.C., 2003. Frequência e intensidade de fenómenos meteorológicos extremos associados à precipitação: desenvolvimento de um sistema de monitorização de situações de seca em Portugal continental. University de Lisboa, Lisboa.

Rodriguez-Iturbe, I., Porporato, A. (Eds.), 2004. Ecohydrology of Water-controlled Ecosystems: Soil Moisture and Plant Dynamics. Cambridge University Press, Cambridge, UK.

Rossiter, R.C., 1966. Ecology of Mediterranean annual-type pasture. Adv. Agron. 18, $1-56$.

Rutigliano, F.A., Castaldi, S., D’Ascoli, R., Papa, S., Carfora, A., Marzaioli, R., Fioretto, A., 2009. Soil activities related to nitrogen cycle under three plant cover types in Mediterranean environment. Appl. Soil Ecol. 43, 40-46.

Saetre, P., Stark, J.M., 2005. Microbial dynamics and carbon and nitrogen cycling following re-wetting of soils beneath two semi-arid plant species. Oecologia $142,247-260$

Sala, O.E., Parton, W.J., Joyce, L.A., Lauenroth, W.K., 1988. Primary production of the central grassland region of the United States. Ecology 69, 40-45.

Serbin, G., Hunt Jr., E.R., Daughtry, C.S.T., McCarty, G.W., Doraiswamy, P.C., 2009. An improved ASTER index for remote sensing of crop residue. Remote Sens. 1, 971-991.

Sudderth, E.A., St. Clair, S.B., Placella, S.A., Swarbreck, S.M., Castanha, C.C., Herman, D.J., Fischer, M.L., Kleber, M.L., Sudderth, E.B., Torn, M.S., Anderson, G.L., Ackerly, D.D., 2012. Annual grassland resource pools and fluxes: sensitivity to precipitation and dry periods on two contrasting soils. Ecosphere 3, article 70.

Swemmer, A.M., Knapp, A.K., Snyman, H.A., 2007. Intra-seasonal precipitation patterns and above-ground productivity in three perennial grasslands. J. Ecol. 95, 780-788.

Tenhunen, J.D., Sala Serra, A., Harley, P.C., Dougherty, R.L., Reynolds, F.J., 1990. Factors influencing carbon fixation and water use by Mediterranean sclerophyll shrubs during summer drought. Oecologia 82, 381-393.

Thomey, M.L., Collins, S.L., Vargas, R., Johnson, J.E., Brown, R.F., Natvig, D.O., Friggens, M.T., 2011. Effect of precipitation variability on net primary production and soil respiration in a Chihuahuan Desert grassland. Glob. Change Biol. 17, 1505-1515.

Unger, S., Máguas, C., Pereira, J.S., Aires, L.M., David, T.S., Werner, C., 2009. Partitioning carbon fluxes in a Mediterranean oak forest to disentangle changes in ecosystem sink strength during drought. Agr. Forest Meteorol. 149, 949-961.

Valladares, F., Sánchez-Gómez, D., 2006. Ecophysiological traits associated with drought in Mediterranean tree seedlings: individual responses versus interspecific trends in eleven species. Plant Biol. 8, 688-697.

Vázquez-de-Aldana, B.R., García-Ciudad, A., García-Criado, B., 2008. Interannua variations of above-ground biomass and nutritional quality of Mediterranean 
grasslands in Western Spain over a 20-year period. Aust. J. Agric. Res. 59, 767-779.

Vicente-Serrano, S.M., Gouveia, C., Camarero, J.J., Beguería, S., Trigo, R., LópezMoreno, J.I., Azorín-Molina, C., Pasho, E., Lorenzo-Lacruz, J., Revuelto, J., Morán-Tejeda, E., Sanchez-Lorenzo, A., 2012. Response of vegetation to drought time-scales across global land biomes. Proc. Natl. Acad. Sci. Biol. 110, 52-57.

Vicente-Serrano, S.M., Lasanta, T., Gracia, C., 2010. Aridification determines changes in forest growth in Pinus halepensis forests under semiarid Mediterranean climate conditions. Agr. Forest Meteorol. 150, 614-628.
Viña, A., Gitelson, A.A., 2005. New developments in the remote estimation of the fraction of absorbed photosynthetically active radiation in crops. Geophys. Res. Lett. 32, L17403.

Weaver, J.E., Stoddart, L.A., Noll, W.M., 1935. Response of the prairie to the great drought of 1934. Ecology 16, 612-629.

Yahdjian, L., Sala, O.E., 2010. Size of precipitation pulses controls nitrogen transformation and losses in an arid Patagonian ecosystem. Ecosystems 13, 575-585.

Yang, Y., Fang, J., Ma, W., Wang, W., 2008. Relationship between variability in aboveground net primary production and precipitation in global grassland. Geophys. Res. Lett. 35, L23710. 